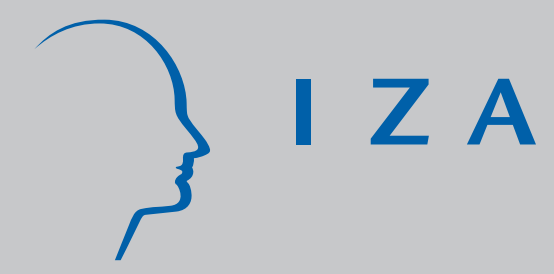

IZA DP No. 292

Between-group Competition in the Labor Market and the Rising Returns to Skill: US and France 1964-2000

Etienne Wasmer

May 2001 


\title{
Between-group Competition in the Labor Market and the Rising Returns to Skill: US and France 1964-2000
}

\author{
Etienne Wasmer \\ Université de Metz, ECARES, ULB, CEPR and IZA, Bonn
}

Discussion Paper No. 292
May 2001

IZA

P.O. Box 7240

D-53072 Bonn

Germany

Tel.: $+49-228-3894-0$

Fax: +49-228-3894-210

Email: iza@iza.org

This Discussion Paper is issued within the framework of IZA's research area The Future of Work. Any opinions expressed here are those of the author(s) and not those of the institute. Research disseminated by IZA may include views on policy, but the institute itself takes no institutional policy positions.

The Institute for the Study of Labor (IZA) in Bonn is a local and virtual international research center and a place of communication between science, politics and business. IZA is an independent, nonprofit limited liability company (Gesellschaft mit beschränkter Haftung) supported by the Deutsche Post AG. The center is associated with the University of Bonn and offers a stimulating research environment through its research networks, research support, and visitors and doctoral programs. IZA engages in (i) original and internationally competitive research in all fields of labor economics, (ii) development of policy concepts, and (iii) dissemination of research results and concepts to the interested public. The current research program deals with (1) mobility and flexibility of labor markets, (2) internationalization of labor markets and European integration, (3) the welfare state and labor markets, (4) labor markets in transition, (5) the future of work, (6) project evaluation and (7) general labor economics.

IZA Discussion Papers often represent preliminary work and are circulated to encourage discussion. Citation of such a paper should account for its provisional character. 
IZA Discussion Paper No. 292

May 2001

\section{ABSTRACT}

\section{Between-group Competition in the Labor Market and the Rising Returns to Skill: US and France 1964-2000*}

This paper describes the changes in the composition of the labor force in the last 35 years and quantifies the substitution of low education / high experience workers by low experience / high education workers by using US and French microdata. The consequences of this substitution on the wage structure are then investigated. In the US, labor supply changes can explain the changes in returns to experience. It also accounts for a part of the increase in returns to education between 1980 and 2000, between $8 \%$ and $20 \%$ depending on the specification. These results rely on panel estimates of a useful concept: the elasticity of substitution between experience and education, which is found to be less than half. In France, the covariations of prices and the supply of skills are consistent with a pure labor supply explanation. Methodologically, the paper shows that the use of a stock measure of efficient units of skills is better than flow measures (e.g. cohort size). It also allows to analyze the consequences of rising female labor participation.

JEL Classification: E34, J21, J31

Keywords: Wage inequality, education, experience, labor supply

Etienne Wasmer

ECARES

Université Libre de Bruxelles

CP 114

Avenue Franklin D. Roosevelt 39

1050 Brussels, Belgium

Tel: +3226504212

Fax: +32 26504475

Email: ewasmer@ulb.ac.be

\footnotetext{
* These are years of the March CPS surveys, thus covering wages for the period 1963-1999. I began this paper when I was at Crest-INSEE and Delta (Paris), and revised it at the Institute for International Economic Studies where I received a fellowship from the foundation Wenner-Grenska Samfundet, and at the CEP, London School of Economics. I want to thank those who helped me in this project, Daniel Cohen, Francis Kramarz and Chris Pissarides. INSEE made the French data accessible. I am extremly grateful to a first anonymous referee, Daniel Verger and Dominique Goux who provided me with their own database. I benefited from illuminating discussions with: Paul Baudry, François Bourguignon, Moshe Buchinsky, Antonio Ciccone, Gilles Duranton, Per-Anders Edin, Richard Freeman, Peter Gottschalk, Bertil Holmlund, Andréa Ichino, Alan Manning and Hillary Steedman, and seminar participants of various seminars : CEP, LSE Money/Macro, Uppsala University, DELTA, FIEF, Pompeu Fabra, ZEI Bonn, ECARES (twice), CEPR in La Coruna, Toulouse-IDEI, Cemfi in Madrid, IIPF 98 in Argentina, EEA and ESEM 98 in Berlin, and EALE 98 in Blankenberge. This paper initially circulated under the title: 'Some Labor Market Consequences of Demographic Changes.' I also thank Christina Lönnblad for editorial assistance.
} 
A great deal of research has been devoted to the study of the changes in the US wage structure and rising inequality in the last decades. ${ }^{1}$ A consensus has emerged: the rising returns to various skills (education, experience, unobserved characteristics) are demand-driven, and rising inequality in the 80 's is certainly caused by biased-skilled labor technical change. These conclusions are most clearly expressed in Bound and Johnson (1992), Katz and Murphy (1992), Juhn, Murphy and Pierce (1993). ${ }^{2}$

To disentangle the effect of labor supply shifts and labor demand shifts, the general idea of this literature is to observe the sign of the covariation of relative wages and relative quantities: for instance, observing a joint increase in the relative wage of type- $x$ workers and an increase in the relative supply of type- $x$ workers, one will conclude that necessarily, the demand for type- $x$ workers has increased, conditional on non-increasing returns to scale in the production function. Applying this logic, the dominant view (labelled A) is that changes in demand were important in the 80's, because of the following facts; A1: the relative supply of college educated workers has increased since the early 70's, while the college premium in wages declined in the 70's but has risen since the early 80's; A2: the relative supply of female workers has increased since the 60's, their relative wage remained constant until the mid 70's, and then increased; A3: the ratio of older to younger workers' wages rose (i.e. the experience premium rose) whereas the size of the cohorts of young workers

\footnotetext{
${ }^{1}$ Notably, Bound and Johnson (1992), Katz and Murphy (1992), Buchinsky (1994), Juhn, Murphy and Pierce (1992, 1993), Levy and Murnane (1991), Freeman (1993, 1995), Topel (1994a and b), and most recently in the Journal of Economic Perspective (1997), the four papers by Gottschalk, Johnson, Topel, and Fortin and Lemieux. International comparisons or non-US studies were made by Blanchflower, Loveman and Katz (1993), Davis (1992), Bertola and Ichino (1995), Goux and Maurin (1995), Card, Kramarz and Lemieux (1997).

${ }^{2}$ To some extent, other factors have contributed to decreasing wages for low-skilled workers (de-unionization, Freeman 1993, or de-unionization for men and minimum wage for women, Fortin and Lemieux 1997). Immigration and international trade are not considered to have a major effect (Freeman 1995, Borjas, Freeman and Katz 1997), even if the latter paper finds "marked" trade effects of the first quintile of the wage distribution.
} 
increased in the 70's, but then declined in the 80's. Facts A1-A3 clearly suggest that demand was an important component of the changes in the 80's.

This paper reinterprets the facts A1-A3 in the following way; B1: Women and young are low experience workers, therefore their increasing supply leads to a scarcity of the experience of the labor force, naturally rising the experience premium; B2: as times goes, the ageing of the baby boom cohorts and female workers accumulating more experience leads to the reverse trend (higher supply of experience), leading to a decline in the experience premium. B3: Experience and education are skills which might be substitutes or complements. Any change in the quantity of experience should affect in one way or another returns to education; B4: The low experience groups, being adversely affected by the supply trend B1, should invest in human capital: young in education, women in careers, on-the-job skills; B4: The low wage groups are to some extent relatively more important in the labor force, so if their human capital investments are not sufficiently high, they should face a decline in their real wage. How can the view B, which gives more weight to labor supply factors, improve our understanding of the long-run evolutions of labor markets? I will be dealing mostly with points B1, B2 and B3, point B4 being the subject of a separate study. It can be observed that, if the view B has not been investigated much so far, this is because the existing literature on rising wage inequality usually relies on the assumption, not always clearly expressed, but not innocuous, that certain labor inputs do not compete with each other; for example men and women, or parttime and full-time workers would work on different islands. ${ }^{3}$ The goal of this paper is to show that

\footnotetext{
${ }^{3}$ Most previous works have focused on people "reasonably attached to the labor markets", thus excluding a large number of part-time / part-year workers, sometimes focusing on men exclusively (Juhn et al. 1993), on full-time / full year workers (Levy and Murnane 1992, p1355), considering men and women separately (as in Card et al. 1995, although their focus is rather on the impact of wage institutions). Katz and Murphy (1992) have considered the joint changes of wages (of full-time workers) and the labor supply of each group (with a weight for hours), but without emphasizing the possible competition between gender. Bound and Johnson (1992) have considered the hourly wage of all workers, but have assumed the same substitutability between different groups.
} 
a new perspective, new results and new interpretations of rising returns to skills can be offered, all three linked to labor supply, once the assumption of an absence of competition between labor inputs is relaxed. Moreover, this assumption must be relaxed to be consistent with the convergent empirical results by Grant and Hamermesh (1982), Berger (1983) and Topel (1994a and b). They all find a strong substitutability in production between women, low skilled men and young workers. To understand their results, one must acknowledge that men and women may well supply their skills in the same markets. Similarly, part-time workers may compete with low skilled, full-time workers. On the role of supply factors, see also Topel (1997) and Card and Lemieux (1999). The latter observe that the overall increase in the supply of educated workers hides a decline for some cohorts.

Accordingly, I will make the radically opposite assumption that competition occurs between all segments of the labor force. One might argue that segregation by gender is too high to reasonably aggregate men and women in the analysis. The view taken here is that high segregation does not imply the absence of competition: competition in some sectors is sufficient to affect the wages of all sectors, since obviously wages are set at the margin. The advantage of making such an assumption is that it allows to consider a potential source of wage evolutions: the conjunction of rising female participation and the increase in the stock of younger workers following the demographic waves of the baby-boom. These trends imply a change in the composition of the skills of the labor force, from more to less experienced workers. Since Katz and Murphy (1992, p73) noted that they had "trouble explaining changes [in returns to experience] in the 80's" with the relative supply of experience measured as age or potential experience (age - education), this papers aims at proposing a supply explanation with a more precise measure of experience, the efficient units of experience, or the level of experience multiplied by its wage return. This method is validated by using a unique French dataset including data on true experience, as opposed to potential experience. 
This paper is mainly motivated by the fact that the source of the changes in demand for skilled labor as implied by A1-3 is unclear. Indeed, those changes are not really observed, but rather inferred from changes in wages and quantities and thus rely on priors on labor demand curves. ${ }^{4}$ Some have claimed that a cause of an upward shift of labor demand curves for skilled workers is 'biased technological changes' due to, for instance, the increased use of computers at work (see Krueger 1993). This is certainly an important part of the story. However, it may not be all the answer, for the following reasons. First, as pointed out by Entorf and Kramarz (1994) and Di Nardo and Pischke (1997), the fact that an employee works with a computer is mainly a proxy for unobserved skills: once controlled for this heterogeneity with panel data or additional variables (like using a pencil at work) the premium associated with computers disappear. In the same vein, Chay and Lee (1997) show that, assuming some correlation between unobserved heterogeneity and education in wage equations, a part of the rising education premia is accounted for by unobserved skills. Second, in the last decades, young workers are probably the group that has suffered most in all OECD countries, and it is difficult to understand why computers should affect them adversely the opposite would rather be the prior, as many models of human capital investment would predict (Ben Porath 1967). Third, as shown in Gottschalk (1997), real wages of males between the first and the sixth decile of the wage distribution have decreased significantly between 1973 and 1994, in relative terms, but also in absolute terms. Although measurement errors in the price index are certainly an issue, one needs a (very strong) net substitutability between skilled and unskilled to explain this fact by technological progress, which is counter-intuitive, or to build a complex story

\footnotetext{
${ }^{4}$ Related to this point, the rise in the supply of educated workers in most OECD countries is not necessarily due to demand for labor : in France, such a rise occured for exogenous political reasons, after the leftist governement of F. Mitterand won the 1981 elections. Higher education is also a consumption good, possibly a superior one, rising with the level of GDP per capita. See also Card and Lemieux (1999), commented above, for cohort effects and the supply of education.
} 
with physical capital, which the literature cited above has not done to my knowledge. ${ }^{5}$ A broader discussion of heterogeneity can be found in Card (2000, IIId notably) where it is argued that, if changes in the magnitude of returns to education is large compared to the ability bias, these changes may be partly due to the "changes in the magnitude of [the ability] component".

Section 1 presents some facts linked to labor supply evolutions. Section 2 discusses how returns to skills may depend on observed changes in quantities of skills supplied, by decomposing skills into experience and education. If experience and education are substitutes factors, any decline in the experience level of the workforce will increase the demand for education. On the contrary, if they are complements, an increase in the experience level of the workforce such as the one observed after the mid 80's, will increase the demand for education. Section 3 develops the measure of the efficient units of experience and check its robustness to potential drawbacks. Section 4 discusses the implications of the results of Sections 2 and 3 for the causes of rising returns to skills. Using the model of Section 2, and the estimates of changes in labor supply from Section 3, part of the wage inequality puzzle can be explained : first and above all, the rise in returns to experience, but also a significant part of the rise in returns to education (between 12 and $20 \%$ of the increase in the college premium and between 8 and $15 \%$ of the increase in returns to each year of schooling). Section 5 concludes.

\footnotetext{
${ }^{5}$ To see this point, assume that there are skilled $S$ and unskilled $U$ jobs, and that the aggegrate production function is $A . F(\tau . S, U) . \tau$ represents biased technical change, and $A$ neutral technical change. New techniques must improve the efficiency of labour, so $A$ and $\tau$ are expected to increase over time. Since the wage of the unskilled is $w_{U}=A \cdot F_{U}(\tau . S, U)$, its variation over time is $\frac{d w_{U}}{w_{U}}=\frac{d A}{A}+\frac{F_{U U}}{F_{U}} \cdot d U+\frac{F_{U S}}{F_{U}}[\tau . d S+S . d \tau]$. With standard assumptions of concavity, $F_{U U}$ is negative. Given the observed evolutions of the educational attainment, $d S>0$ and $d U<0$. With $d \tau$ and $d A$ positive, a decline in $w_{U}$ necessarily implies that $F_{U S}<0$, which implies a net substitutability.
} 


\section{Experience in the Labor Force: Some Facts}

Tables 1 and 2 document the changes in the age and gender composition of the labor force in various OECD countries. It appears clearly that there are more women and to some extent, more 25-34 year old workers in the active population. ${ }^{6}$ These important supply evolutions may have to some extent contributed to a decline of the average quality of the labor force: indeed, young and women have low wages. Table 3 illustrates this latter point: the first column represents the different percentiles of the distribution of female hourly wages. The other columns represent, for various years, the position of this percentile in the male wage distribution. The message of the table is that, despite some progression in the relative wages of women over the period (the median hourly wage of women progress from the 21 st to the 35 th percentile of males wages), the wages of women were and still are rather concentrated in the lower deciles of the distribution of males wages: note that until the late 1980 's, $90 \%$ of women wages were located in the first six deciles of men's wages.

To document further in this idea of increased supply of low wage workers, one can investigate the distinctive feature of both young and women: employment experience. For that purpose, I used data from the French survey Actifs Financiers 1992. This is a unique dataset where individuals declared their number of years in part-time and full time employment, since their entry into the labor market. ${ }^{7}$ Potential experience is defined as age minus age at end of schooling and true experience is defined as the number of years in employment. To my knowledge, no comparable dataset exists in the US: only panel data make possible the estimation the number of years in

\footnotetext{
${ }^{6}$ Europe (12) refers to the 12 members of the European Union, Europe (11) excludes Greece for which no data are available before 1977. The choice of those older than 25 was made to avoid any interference with the rising enrollment in higher education.

${ }^{7}$ Daniel Verger (INSEE-CREST) provided me with an updated dataset including a correction for some misreported variables (spells of employment due to complicated trajectories, correction for domestic employees). The description of the variables and the instruments is in the appendix.
} 
employment, with huge problems of imputation and attrition. However, given the similarity of labor supply trends across the OECD, it will be argued that some inference can be made for the U.S. case as well.

Table 4 reports real experience and potential experience in different cells of the French active population (self-employed excluded). The first row represents the average (potential or real) experience of all active men (or women), rows 2 to 5 sort individuals according to potential experience and the last 4 rows sort them according to the quartile of hourly wage (in this case, the sample is restricted to the employed population). It appears quite clearly from the tables that even in 1992, the average real experience of women was by $16 \%$ lower than their potential experience. When compared to men, it appears that high skill women actually have experience levels similar to those men have: the relative gap between real and potential experience is $16-17 \%$ for the first two quartiles, and about $9 \%$ for the last two quartiles, close to the average of men. These averages in the different cells do not only reflect the participation behavior of workers in 1992, but also the history of the labor force. It appears that there are much larger differences between actual and potential experience for oldest women (exp $>30$ ), i.e. about $22 \%$, while the corresponding figure is $3.5 \%$ for men.

Beyond gender differences in the average true experience, there are also significant gender differences in returns to true experience, about $40 \%$. To show this, I estimated different wage equations with true experience or with potential experience

$$
\log \left(w_{i}\right)=C+\alpha \cdot E_{i}+\beta \cdot X_{i}+\epsilon_{i}
$$

and higher order terms (quadratic experience, or interaction terms) not included here for convenience. The complete results of the regressions are reported in table 20 in the Appendix with GLS or IV estimators. These regressions can be used for calculating the average returns to experience for men and women. See table 5. The first and second rows represent the coefficient on experience 
and experience square. Rows 3-6 represent returns to 10, 20, 30 or 40 years of 'true' employment experience, taking the concavity in returns to experience into account. The average returns for men after 20 years (the average experience of the active population) is $45 \%$ higher than for women: it is $3.34 \%$ for men whereas $2.16 \%$ for women. To compare with returns to education, the regression shows that the average returns to twelve years of schooling is equivalent to 13 years of experience for men and 23 years of experience for women: experience is thus an important component in wages.

For a flavor of the US changes in true experience, table 6 shows some tabulations from the March CPS of age, potential experience and number of years of schooling for American male active workers aged 16-64 (the definition of the variables is postponed to Section 3). Until the early 80's, there was a decline in the average level of experience, as well as a decline in the average age, and then the trend was reversed. Note, however, that the decline in experience is only marginally due to the rising level of education; between 1965 and 1980, the average level of experience declined by 4.3 years, whereas the average level of education increased by 1.3 years only. After 1980, the trend has reversed and one observes a substantial increase in the average age and experience of male participants.

It is recognized that potential experience is a bad proxy for women's true experience, understating their increasing participation rates over time, so we do not present any result with female workers. Accounting for their rising participation in the previous table, it would however amplify the decline in experience in the first part of the sample (given their lower average experience). In the second period, it would attenuate the upward trend in experience levels, provided that the latter composition effect (women have less experience than men) dominates over the upward trend of women's experience itself. These central questions are addressed later, in section 3.

The general conclusion of this section is simply that, with an increasing number of young and 
women in the labor force, a decrease in the average number of units of experience supplied by the labor force participants should be expected, in absolute terms or in efficient units, followed by the reversed trend as the cohorts become older and more experienced.

\section{Some Theory}

To evaluate the impact of the changes described in Section 1, it should be noticed that they imply a decrease in the average skill of the labor force, at a constant level of education of the labor force participants. To make this point clear, consider first what would happened in absence of changes in the average level of education. The negative trend in experience implies a relative scarcity of skills, followed by the reverse trend. Thus, the price of skills should change: certainly the price in experience, but maybe also the price of education, provided that education and experience are imperfect substitutes for each other.

The intuition can be captured with some algebra. Assume a production function $Y=F(L, \bar{H})$ where $L$ is some fixed factor in the short-run (either unskilled labor, everyone being endowed with one unit of $L$, or physical capital, land). This factor is unimportant, just needed to have decreasing returns to scale in the other factor $\bar{H}$, an aggregator of the human capital of the individuals in the labor force : $\bar{H}=\sum_{\text {individuals }} h\left(X_{i}, E_{i}\right)$. In addition, there is an informal sector with a linear productivity, which yields an income denoted by $C$. Given decreasing marginal returns on unskilled labor, the interior solution is such that the wage of the unskilled in the formal sector is $w_{L}=F_{L}=C$.

Ignoring complex aggregation issues, I further assume that $\bar{H}$ depends on aggregate education and experience and can be written as $\bar{H}=H\left(\tau_{E} \cdot \bar{E}, \bar{X}\right)$ where $\bar{E}$ and $\bar{X}$ are aggregate human capital acquired through education and experience respectively; $\tau_{E}$ is a technological parameter representing the demand for education. The aggregate quantity of experience supplied $\bar{X}$ is an aggregation of the experience of individuals, which might be combined with their education: $\bar{X}=$ 
$\sum x\left(X_{i}, E_{i}\right)$, and similarly $\bar{E}=\sum e\left(E_{i}, X_{i}\right)$. The production function can thus be rewritten as $Y=F\left(L, \tau_{E} \cdot \bar{E}, \bar{H}\right)$. In the spirit of human capital models, I assume aggregation to be linear (e.g. see Freeman, 1986, p358), i.e. $\bar{E}=\sum F_{E} \cdot E_{i}{ }^{8}$ and $\bar{X}=\sum F_{X} \cdot X_{i}$. Note that the benchmark human capital model is a specific case of this formulation, when $\bar{E}$ and $\bar{X}$ are assumed to be perfect substitutes in $\bar{H}$. For the purpose of this paper, it is however interesting to assume imperfect substitutability. The skill premium can be decomposed into two parts: one rewarding education, $w_{E}=F_{E}(\bar{X}, \bar{E})=\tau_{E} \cdot h_{E}(\bar{X}, \bar{E})$, and one rewarding experience, $w_{X}=F_{X}(\bar{X}, \bar{E})$.

This setup allows us to estimate to what extent returns to education have changed in response to technology $\left(\tau_{E}\right)$ and in response to the changes in the supply of education $(\bar{E})$ and to the changes in the supply of experience $\bar{X}$, driven by demographic changes. Indeed, differentiating $\log \left(w_{E}\right)$ with respect to quantities $\bar{X}$ and $\bar{E}$ gives:

$$
\frac{d w_{E}}{w_{E}}=\tau_{E} \cdot \frac{F_{E E}}{F_{E}} \cdot d \bar{E}+\frac{d \tau_{E}}{\tau_{E}}+\frac{F \cdot F_{E X}}{F_{E} \cdot F_{X}} \frac{\bar{X} \cdot F_{X}}{F} \cdot \frac{d \bar{X}}{\bar{X}}
$$

In (1), the changes in returns to education are the total of three terms ${ }^{9}$. The first represents a supply effect, and an increase in education $(d \bar{E}>0)$ is expected to reduce returns to education given $F_{E E}<0$; the second is the possible impact of biased technological change; the third and fourth terms represent the impact of the change in the skill composition of the labor force. The elasticity of complementarity $1 / \sigma=\frac{F \cdot F_{E X}}{F_{E} \cdot F_{E}}$ plays here a key role : it is negative if the two factors are q-substitutes and positive if the factors are q-complements.

A joint increase in $\bar{E}$ and $w_{E}$ does not necessarily imply that the second term (biased technological progress) is required. It may well be that the product $d \bar{X} / \sigma$ is positive: then the third term is also positive, thus reducing the size of the trend $\left(d \tau_{E}\right)$ necessary to explain the changes in the

\footnotetext{
${ }^{8}$ An other aggregator considered at times is $\bar{E}=\exp \left(\sum \phi_{E} \cdot E_{i}\right)$, where $\phi_{E}$ is the relative price of education, but in this case, it would make no qualititive difference with respect to the linear aggregator.

${ }^{9} d L$ is assumed to be zero in the short-run.
} 
wage distribution. To fix ideas, consider the simple production function

$$
Y=L^{1-\delta} \cdot \bar{H}^{\delta}=L^{1-\delta} \cdot\left(\bar{E}^{\rho}+\bar{X}^{\rho}\right)^{\delta / \rho}
$$

where $\rho$ is smaller than 1 . In this CES specification, we have $1 / \sigma=\frac{\delta-\rho}{\delta}$. It follows that if $d \bar{X}(\delta-\rho)>0$, the trend $d \tau_{E}$ is necessarily smaller than what is usually estimated, whereas the opposite holds if the product is negative. Sections 3 and 4 develop this idea.

\section{Measurement of skills}

This section proposes a method for measuring the changes in $\bar{X}$ and $\bar{E}$ over time. For this purpose, I estimate the price of each skill (diploma and experience) with two wage equations, one for men and one for women on 5 dummies for each educational level ${ }^{10}$ and on potential experience and its square

$$
\log \left(w_{i}^{T}\right)=C+\alpha_{T} \cdot E_{i}+\beta_{T} \cdot X_{i}+\epsilon_{i}
$$

where $E_{i}$ denotes the educational level of individual $i$, and $X_{i}$ his/her experience level (the specification includes a quadratic term in experience). ${ }^{11}$ Additional control variables are described in the Appendix. Then $\widehat{w_{i T}}$, defined as the predicted value of wages (i.e. the conditional mean wage), can be decomposed into an intercept, the experience component and the education component. Each

\footnotetext{
${ }^{10}$ The fourth and the fifth levels of education in France coreesponds to 14 years of schooling, and more than 15 years of schooling respectively.

${ }^{11}$ With the production function of Section 2, the wage of an individual with experience $X_{i}$ and education $E_{i}$ will be $C+w_{E} \cdot E_{i}+w_{X} \cdot X_{i}$, and its log will be approximated (after a first-order Taylor approximation) by $\log (w)=$ $\log C+\frac{w_{E} \cdot E_{i}+w_{X} \cdot X_{i}}{C}$ plus some quadratic terms, and thus $w_{E}$ and $w_{X}$ can easily be estimated. Then $\alpha_{T}=w_{E} / C$ and $\beta_{T}=w_{X} / C$. Note that the reference group here will be the workers with neither experience nor education, whose wage is equal to $\mathrm{C}$ given the existence of the unformal sector. All can equivalently be expressed, not in terms of education premium relative to the uneducated, or in terms of experience premium relative to the unexperienced, but directly in terms of education premium relative to experience premium. I am indebted to Peter Gottschalk for this point. In this case, $w_{E} / w_{X}=\alpha_{T} / \beta_{T}$ is the relevant quantity to consider.
} 
component is averaged across the labor force. For instance, in 1970, the education component $<E_{i}>=1 / N \sum_{i=1970} \alpha_{T} \cdot E_{i}$ was the average education of individuals in the labor force in that year, at the market price of year $T$. This method provides a decomposition of the average productivity of the labor force in efficient units of education and in efficient units of experience. Such an exercise will be conducted at constant prices estimated for different years. However, data limitation will create some biases which can be treated as follows.

\subsection{Potential Problems}

\subsubsection{Gender Discrimination}

The extent to which gender discrimination may affect the estimation of the efficient units of skills supplied is a possible issue. It may be that the gender gap in wages or in the wage returns to education or experience only reflects some discrimination against women and not actual productivity. In the wage equations described above, the wage gap between men and women is partly captured by differences in the intercept, whereas the decomposition is only based on the coefficients of the wage returns to observed skills. However, discrimination may also affect the wage returns to skills. Denote by $\lambda$ the degree of discrimination against women, defined as follows. Let $\alpha_{M}$ be the measured price of a given skill for men and $\alpha_{F}$ the measured price of the skill for women. The returns to skills for women corrected for discrimination $\alpha_{T}^{\text {corr }}$ is:

$$
\alpha_{F}^{c o r r} \cdot(\lambda)=\alpha_{F}+\lambda \cdot\left(\alpha_{M}-\alpha_{F}\right)
$$

With $\lambda=0$ (no discrimination), $\alpha_{F}^{\text {corr. }}(\lambda)=\alpha_{F}$. With $\lambda=1$ (full discrimination), $\alpha_{F}^{\text {corr. }}(\lambda)=\alpha_{M}$. I will provide the estimates of the decomposition of wages into the two components when taking different values of $\lambda$ in the Appendix. 


\subsubsection{Interaction Terms between Education and Experience}

It might be that the decomposition of wages in education and experience described by equation (2) neglects significant interactions between experience and education. Therefore, an interaction term should be added in the econometric specification as in

$$
w_{i T}=C+\alpha_{T} \cdot E_{i}+\beta_{T} \cdot X_{i}+\gamma_{T} \cdot E_{i} * X_{i}+\epsilon_{i}
$$

Accordingly, the changes in the skill level of the labor force should be represented in a three dimensional space (education, experience and interaction). However, both in France and the US., the size of the interaction term and its changes are small compared to the two other dimensions. Therefore the conclusion of the two-dimensional decomposition will remain valid.

\subsubsection{Measurement Error on Female Experience}

It is a well known fact that some women may have an actual experience which is much lower than what is measured by potential experience due to recurrent interruptions of activity. Assume that the true experience for women is determined by the following model:

$$
T X_{i}=v \cdot P o t . X_{i}+\theta_{i}
$$

where $T X_{i}$ and Pot. $X_{i}$ are true and potential experience, $\theta_{i}$ is a random error term with variance $\Sigma^{2}$ and $v<1$ is a systematic error. If $\Sigma>0$, there is a downwards bias to the OLS estimates of the elasticity of the coefficient on experience, by a factor $v \cdot \frac{\left(T X_{i} \cdot T X_{i}^{\prime}\right)^{-1}}{\Sigma^{2}+T X_{i} \cdot T X_{i}^{\prime}}$. When $\Sigma$ goes to zero, the second part of the product goes to 1 . In addition, the coefficient is biased by a systematic factor $v$. It follows that the number of efficient units of experience estimated for an individual will

be biased by the factor $v \cdot \frac{\left(T X_{i} \cdot T X_{i}^{\prime}\right)^{-1}}{\Sigma^{2}+T X_{i} \cdot T X_{i}^{\prime}} \cdot 1 / v$, and it can be seen that the systematic error $v$ can be eliminated in the product of the variable and its coefficient. To the extent that much of the error on experience is a systematic one, the problem of measurement error is small. This problem is addressed in section 3.4 with data on true experience. 


\subsubsection{Experience vs. Seniority}

In the cross-sectional analysis that follows, it is impossible to disentangle the wage effects of general experience and firm specific experience (seniority, tenure). By measuring experience, this paper actually includes both types of human capital. Does that affect our analysis? The answer is probably no, with however a restriction. Assume that human capital linked to experience $h_{i}$ of individual $i$ is the sum of tenure $T_{i}$ and total experience $X_{i}: h_{i}=a \cdot T_{i}+X_{i}$, the coefficients $a$ reflecting a difference in the efficient units of each type of human capital. First, if $a$ is small, i.e. if wage rise only because of experience, our analysis is correct. Such a conclusion about the relative importance of seniority and experience in individual wage growth was reached by Altonji and Shakotko (1987), Abraham and Farber (1987), although there is still an empirical debate. Second, even if $a$ is high, if tenure and experience are highly correlated across individuals, $T_{i}=c X_{i}+\xi_{i}$ then $h_{i}=(a c+1) \cdot X_{i}+\xi_{i}$ and the estimates of the impact of $h_{i}$ on wages would be biased only if $\xi_{i}$ was correlated with workers' unobserved quality. This potential problem is generally absent in the overall debate on the rising returns to skills, and one would need important changes in the patterns of these correlations over time to challenge the conclusion of the approach of this paper.

Note however that, along the line of Juhn et al. (1993) for instance, these returns estimated from the cross-section truly account for the effect of an imbalance in the supply of young with respect to older workers, or of high experienced with respect to low experienced workers : at any point in time, the cross-sectional composition of skills determines the returns to these skills. So the analysis we undertake here, aiming at capturing the effects of such imbalance in the supply of skills, is fully relevant.

\subsection{March CPS data, 1964-2000}

Wages and labor force data are derived from the March Current Population Survey. Hereafter the year refer to the year of the survey, which implies that the earnings and the hours worked are those 
of the previous year. See Appendix 1 for a description of the data.

To provide an accurate comparison between the two countries, the wage equations described above will be estimated, using the same specification on a sample of employed workers. ${ }^{12}$ See the table 21 in the Appendix, which shows rising returns to education, especially after the mid 70's, rising returns to experience for men, and the increase in the variance of residuals. Using those coefficients, wages can be decomposed into two different components, according to education and experience, as in table 7. For education, there are two possible specifications in the wage equation (2) : the first one is to use five dummies for each educational group. The second one, perhaps easier to interpret with respect to human capital theory, is to assume a linear term for the years of schooling. The first specification is hereafter denoted by $5 D$, the second one by lin. The qualitative results being the same in section 3 , I insist on the $5 D$ specification. The results differ more across specification in section 4, and I will explore the differences more systematically. All specifications have in addition a control for the variable _race.

In table 7, the efficient units are expressed at the 1964, 1980 or 1991 prices of skills, and individuals are weighted in the aggregation with both family weights and hours worked. Since the qualitative results are the same, I only comment on the results with the 1980 prices. It appears that the average level of experience decreased strongly in efficient units until 1977, and then increased slightly but never recovered its initial level. The evolution of education is as could be expected: it increased sharply over the entire period. The evolution of the skill composition of the labor force (without weighting for hours worked) is represented in figure 1. The skill composition of the

\footnotetext{
${ }^{12}$ The CPS allows to estimate not only the wage of the currently employed, but also of the non-employed who worked at least one week in the year preceding the survey. This is very convenient to treat the sample selection bias which is due to unemployment, since most unemployed workers in the US worked during the previous twelve months. The regressions were done on the whole sample of active workers, or on the sample of employed workers, without very significant differences.
} 
employed population (unreported) has a very similar evolution. The small break between 1991 and 1992 on the figure is due to a change in the definition of educational variables in the CPS surveys (see Appendix 1) that could not be totally corrected for, without consequences in subsequent results. ${ }^{13}$ The robustness of the time series evolution of the skill composition of the labor force is investigated by imposing that women's true returns to skills is equal to returns to skills estimated on a sample of men (i.e., in equation (3), $\lambda=1$ ). Figure 2 displays the results. The general evolution is the same, but the level of experience reached in the 90's goes beyond the level reached when $\lambda=0$ : with the specification $\lambda=1$, women are paid more for their experience. This analysis reveals that if the experience level in the late 80's has not reached the level of the 60 's, this is not really due to a change in the age structure, but rather to a change in the gender composition of the labor force. Intermediate values of $\lambda$ are reported in the Appendix of Section 3 (table 23). Whatever the chosen value for $\lambda$, the conclusion is not qualitatively changed.

Having different weights in the summation across the labor force (weighting for weekly hours worked as in the tables) or including additional variables (region, one-digit industry, union status) does not modify the picture. Similarly, the inclusion of the interaction term in Eq. (4) does not change the conclusions (one can refer to the earlier version of this paper). Figure 3 shows the result of the decomposition with a linear specification for schooling, again with similar results.

Finally, it is important to notice that the axis for education and experience have a similar scale : the magnitude of the changes in the supply of education and of the supply of experience is the same. Accordingly, considering fluctuations in experience supplied by the labor force is crucial in an analysis of the changes in the wage returns to skills.

\footnotetext{
${ }^{13}$ The inclusion of 'dummy' taking values 0 before 1992 and 1 afterwards was never significant in the regressions presented in 4.2 .
} 


\subsection{French FQP data, 1970-93}

The same analysis is applied to France. Wages and employment data are taken from the survey Formation et Qualifications Professionnelles on French workers. Since no race variables are available, the specification only includes experience and education. In table 22 reported in the Appendix, one can observe the continuous decline in the coefficients on education, the rise in returns to experience for women and, to some extent, for men, and the stability in the variance of the residuals except in the last part of the period after 1985.

The results of the decomposition of wages along the two dimensions for the employed population are displayed in table 8 . It can be observed that at constant 1970 prices, there is a strong increase in the supply of education and a decrease in the quantity of experience until 1985, and then experience remains more or less constant. Similar conclusions emerge when one considers the price of skills in 1993 (third columns in the tables). The evolution of the skill composition of the labor force is also presented in figure 4 and 5 . At a constant price, this represents the shift in the composition of the skills of the labor force, that is, more education and less experience, as in the US.

Here again, the decomposition between an experience and an education term in wage determination does not drive the result. Estimating a richer specification including linear experience terms by diploma level, as in equation (4), the same conclusions holds. Finally, allowing for discrimination by taking different values of the coefficient $\lambda$, as in the US, does not change the picture. The quantity of education supplied increased in all columns of table 24 in the Appendix, and the quantity of experience supplied decreased between 1970 and 1977 in all cells and then remained more or less constant, except maybe when $\lambda=1$ : in this case, in 1993, the term $<X_{i}>=1 / N \sum_{i=1993} \alpha_{T} \cdot X_{i}$ goes back to the 1970 level.

Finally, the scale of the 'experience' axis also indicates that demographic changes occurred much more slowly in France than in the US. 


\subsection{True Experience}

This sub-section aims to check that the previous conclusion is not dependent of the use of "potential experience" instead of "true experience". Due to the error in approximating true experience by potential experience, the source of bias in the estimations of the efficient units of education and experience is twofold. The first one is a systematic downward bias, since only a fraction of the cross-sectional variance of true experience is explained by potential experience. To estimate the magnitude of these effects, I first perform a regression of true experience on potential experience. The regression on the sample of employed men has a R-square of 0.89 with a coefficient of 0.88 (0.01), and the regression on the sample of employed women has a R-square of 0.69 with a coefficient of $0.76(0.02)$. This is sufficiently high to think a priori that the systematic bias on the efficient units of experience in the labor force will be weak.

The second is an endogeneity bias: the correlation between the error on experience and education is not equal to zero, which also affects the estimates of parameters $\alpha_{T}$ in the model. As table 9 indicates, the correlation coefficients between the experience gap and the educational dummies 2, 3 and 4 are generally significant, although small, about $8-15 \%$. There is, however, a possibility that the wage equations are biased because of these correlations, or due to the random error on experience.

Accordingly, the magnitude of both biases has to be checked. Using the 1992 cross-sectional dataset of Actifs Financiers, I perform two wage equations with either true or potential experience, in order to check that the bias on the coefficients is small. Table 10, reporting the coefficients for education and experience according to the specifications, shows that this is the case. It can be seen that, after all, the difference in the coefficients is quite small. These coefficients are then used for calculating:

- the efficient units of education, equal to 0.342 (0.31) with the specification I (true experience) 
and equal to $0.342(0.31)$ with the specification II (potential experience), i.e. no difference.

- the efficient units of experience, equal to $0.496(0.18)$ with the specification I, and equal to $0.513(0.17)$ with the specification II, i.e. a $3.3 \%$ upward bias with potential experience.

Under the assumption that the bias has not been varying too much over time, it means that the variations in the number of efficient units of experience observed over time in the previous section are probably not dependent on the use of potential experience. In any case, the variations were larger in magnitude than those $3.3 \%$ : about $15 \%$ to $20 \%$ in the US. The conclusions of section 2 may not be too strongly affected by the measurement error on true experience.

However, the true experience data of French women in 1992 make it difficult to be to assertive about the bias for the measurement of efficient units of experience of US women of the early 70's. One can only argue the following : a) to the extent that french female participation is lagging behind the US by a few decades, the bias for the US. should be small in the 70's ; b) slow growth of female participation in France may equivalently lead to a small bias in the 70's in France, since it implies that the bias did not change much over time ; c) finally, in the 90's in the US, female participation is qualitatively the same as male participation, so that the random component of the error should be small, according to the conventional view on the quality of the 'potential experience' proxy for male workers.

\section{Implications for the Labor Demand Shift Hypothesis}

\subsection{Summary of the facts}

To summarize, figures 6 to 8 compare the evolution of returns to education and experience and the quantity supplied, in the US and France. ${ }^{14}$ This reveals that 3 of the 4 panels are consistent with pure labor supply stories.

\footnotetext{
${ }^{14}$ For France, the price of education is calculated as the Baccalauréat premium for men with respect to CEP/BEP (a $4 D$ specification). For the US., the $5 D$ specification allow to measure the price of education as the college premium
} 


\subsubsection{France}

Indeed, in France, the skills supplied in increasing proportion (education) have had a lower returns over time, whereas the skills having become relatively scarce (experience) have had an increasing return. The picture is however slightly less simple as that, because the minimum wage rose strongly over the period 1970-93 in France, which creates a tendency to compress the wage distribution and decrease returns to skills. So I estimated the price of skills with the entire sample of employed men (priceedu1 and priceexp 1 in figure 6), and also with a sample of those a priori not affected by the minimum wage, i.e. removing the first quartile (priceedu2 and priceexp 2 ). The downward trend on returns to education can be observed in the two specifications, whereas the upper trend in returns to experience is observed in the high wage sample only. The returns to experience measured on the entire sample actually decreased. The difference between the two samples indicates a significant impact of the minimum wage in the reduction in wage inequality. Two further remarks are in order here : first, recent studies in France found significant effects of the minimum wage on female employment (Laroque and Salanié, 1999) and smaller though significant effects on youth employment (Kramarz and Philippon, 2000). Second, our theoretical model with wage rigidities has the following implication : a decline in the supply of experienced workers would be partly followed by a rise in the experience premium, to the point where the wage constraint for inexperienced workers becomes binding : at this stage, female and youth unemployment would rise. These predictions were explored and tested in other papers by the author (see notably Wasmer 2001).

with respect to high school of male workers, the linear specification leads to the return to one year of schooling. The price of experience is calculated as, in both countries, the average return to experience over the 20 first years. Similar results are obtained when considering an average of men and women's price for skills. 


\subsubsection{The US}

In the US after the mid 80's, the rise in experience is associated with a decline in returns to experience. See figure 7 and its scatter view, figure 8, showing the results of both specifications (5D and lin). When pooling all labor inputs, the changes in the price of experience are consistent with a labor supply story. Notably in figure 8, the left panels show a very strong negative slope identifying (as shown in 4.2) a relative labor supply curve. In quantitative terms, the correlation coefficient between supply and the price of experience in the U.S. between 1964 and 2000 is -0.85 (-0.88 on the period $1964-1980$, and -0.76 on the period $1980-2000)$.

With other unreported specifications (notably, using different weights of individuals, or with $\lambda=1$ ) one also finds strongly negative correlations. The latter point indicates that the results won't qualitatively rely on the working hypothesis (pooling men and women), since with $\lambda=1$, women are assumed to supply almost as much experience as men. Higher values of $\lambda$ actually increase their magnitude. This illustrates the robustness of our measure of skills based on the wage equations : what is measured here the true stock of skills, a clear improvement with respect to previous studies using the size of the cohorts as an indicator of the supply of low experience workers which is a flow measure of skills.

The previous paragraph illustrates that the labor supply side of the labor market, as expressed in terms of experience, has been under-exploited : it has a high potential to explain changes in the cross-sectional returns to experience. Still, the U.S. exhibit a large positive covariation between the supply of education and its price in the US to be accounted for: the correlation coefficient between the quantity and the price of education is strongly positive: +0.76 . Interestingly, the correlation coefficient on sub-periods had different signs : it is equal to -0.58 for the period 1964-80 and +0.97 for the period 1980-2000). In other words, what has happened to returns to education in the 80's in the US seems unique. Can we explain this positive correlation and the related demand factors 
behind these positive covariations in price and returns to education? The following lines make an attempt to understand whether the supply factors linked to experience can partially contribute to unexplained rising returns to education.

\subsubsection{Rising returns to education in the US : an interpretation of the data}

The model in Section 2 represents a framework for answering this question: one can estimate to what extent the right-hand side $\frac{d w_{E}}{w_{E}}$ is explained by the variation in the quantity of experience by using the results of Section 2. As a measure for $w_{E}$, I have taken both returns to schooling and the difference in the coefficients dip4 and dip2 for men (ratio college / high school). In table 11, the first two rows indicate the change in returns to education over the period, the third row reports the change in experience at the 1980 price measured with different specifications, and the last rows calculate the fraction of the changes in returns to education explained by the changes in experience with the linear specification, i.e. $\eta=\left(\frac{F \cdot F_{E X}}{F_{E} \cdot F_{X}} \frac{\bar{X} \cdot F_{X}}{F} \cdot \frac{d \bar{X}}{\bar{X}}\right) /\left(\frac{d w_{E}}{w_{E}}\right)$. For the latter rows, I have chosen the share of human capital in production $\delta=1 / 2$. Accordingly, and since the U.S. average over the period being that the contribution of experience to wages is about half of the contribution of education, $\bar{X} \cdot F_{X} / F=0.2$. In the regressions of the next sub-section, since one estimate directly $\frac{F \cdot F_{E X}}{F_{E} \cdot F_{X}} \frac{\bar{X} \cdot F_{X}}{F}$ through the coefficient on experience, these values have no impact at all on the estimates of $\eta$. They only have some impact on the estimates of $\sigma$.

One can observe in table 11 that the only periods in which there is a significant increase in returns to education are the 80 's and the 90 's, in bold in the table. Accordingly, the paper focuses hereafter on that period. If education and experience are believed to be strongly substitutes $(\rho>0)$, nothing can then be explained by the term $d \bar{X}$. To the extent that they are complements $\rho<0$, it is possible to explain a significant part of the increasing returns to education over the sub-periods 1980-90, 1990-2000 and 1980-2000 (in the latter case, between 5\% and 44\% depending on the value of $\rho$ in the interval $[-5,0]$ i.e. $\sigma$ in $[0.1,1])$. Other time interval are presented in the table, 
for completeness. Note that accounting for gender discrimination would increase the term $d \bar{X}$ significantly (with $\lambda=1$, it would be increased by 50\%) and thus $\eta$ would rise in proportion.

\subsection{On the elasticity of substitution between education and experience}

\subsubsection{US aggregate time series}

As clear from the previous analysis, the key parameter here, when assessing the importance of introducing the changes in the supply of experience, is the elasticity of substitution between education and experience. It is therefore natural to try to estimate this value. To fix ideas, one may estimate equation (1) year by year, with and without the variable $\bar{X}$, and to see the difference in the magnitude of the trend. As Katz and Murphy (1992), I do not consider this type of regression with 37 observations (one per year) to be definitive evidence, but rather a suggestive way of summing up the results. Tables 12 display the results for the level estimates with both the linear specification and the '5 dummies' specification for education. ${ }^{15}$ First order autoregressive terms are added. In the '5D' specification, the inclusion of a second order term drives the DW statistics to 2.07 but do not change the coefficients, so that I do not report it here. The trend in returns to education declines from $4.68 \%$ a year (resp. $3.81 \%$ ) to $2.4 \%$ (resp. $3.07 \%$ ) when the experience term is added. The reduction is large, respectively $67 \%$ and $22 \%$. I prefer however to consider the estimations in first difference (table 13), since they also allow to estimate $\sigma^{-1}$ and $\eta$. The trend is thus dropped and the constant has to be considered instead. This specification however leads to contradictory and disappointing results : the cross-coefficient is not estimated significantly, and the autocorrelation terms have opposite signs depending on the specification. The lack of variance

\footnotetext{
${ }^{15}$ The missing observation for year 1994 (absence of information on the labor market status, as reported from Unicon, cf. appendix) is interpolated from 1993 and 1995. This has no consequence for the estimates in level, and avoids losing two or more observations when first differences or autoregressive terms are included in the specifications. Estimates without the interpolation are qualitatively the same.
} 
and possibly the change in the definition of education after 1991 explain the difference. One should thus be careful when drawing conclusions here.

\subsubsection{Regional estimates}

To improve these estimates I next consider the joint evolutions of returns to skills and their supply in different geographical areas. It was possible to exploit 21 such geographical subdivisions consistently between years 1964 and 2000. See the appendix for more details. The regional supply of skills is still evaluated at the 1980 price of skills, using the aggregate US price of skill as well (so that to really compare the changes in supply cross-states without interferences with possible regional differences in returns to skills). The figure 9 shows the evolution of the supply of skills for 20 states. The coherence of the evolutions of labor supply across states is striking. In contrast, figure 10 and 11 (resp. lin and 5D) indicate that there are more erratic movements in the regional estimates of returns to skills. This is partly due to small sample size in each cell. Still, it is possible to recognize a rise and a decline in returns to experience, and a clear upward trend in returns to schooling after 1980.

The specifications for education (lin or $5 D$ ) are compared systematically here, since the latter will provide in average larger estimates of $\eta$. Given the small number of observations in some of the regional units, estimated returns to college with respect to high school was negative, leading to five (out of 777) observations dropped when logarithm of the returns were taken.

The estimator is a two stage GLS procedure, attributing cross-sectional weights as the inverse of the variance of the first stage and correcting for cross-sectional heteroskedasticity. Accordingly, and despite the high frequency components, one obtains enough variance to obtain a new set of estimates of the trend and the elasticity of substitution between experience and education. The results are displayed in tables 14 and 15. I investigate several specifications (lin, $5 D$, level, first differences) always with regional-specific autoregressive errors. With the linear specification in levels, the trend 
with F.E. (calculated as an unweighted average of the fixed effects) is reduced by $10.6 \%$ a year. It is larger with the $5 D$ specification (-30\%). A robustness check not reported here, allowing the trend to differ over the period 1964-80 and 1981-2000, shows that the trend over the first period is small or insignificant and does not depend on the specification, and that the trend over the second part of the period declines by about the same magnitude (resp. 11 and $30 \%$ ) as soon as experience is added to the specification. Note that the DW statistics in panel are calculated as an average of the regional DW, which means that the usual p-values do not apply.

In first difference, one can obtain a precise and very convergent estimates of $\sigma$, obtained from the coefficient of $\Delta \ln \exp _{t}$ as coeff. $=0.2 / \sigma$. The SD of $\sigma$ is then obtained by the application of the delta formula (asymptotically valid). The value of $\sigma$ is about one third with the linear specification, and about one fifth with the $5 D$ specification, with a SD of 0.15 (resp. 0.08), indicating a fairly large complementarity between the two types of human capital. The implied value for $\eta$ over the period $1980-2000$ is then equal to 0.11 with an associated confidence interval of $[0.08 ; 0.15]$ and $50 \%$ larger with the $5 D$ specification, $\eta=0.15$ with a confidence interval of $[0.09 ; .0 .21]$.

As seen earlier, the larger $\lambda$, the larger the rise in the supply of experience, and the larger $\eta$. These results may be interpreted as a lower bound of the effects of experience, although it is difficult to estimate which value of $\lambda$ should be chosen : a value of $\lambda=1$ drives $\eta$ to 0.16 [0.12 ; 0.23]) with the linear specification.

\subsubsection{Returns to Experience and Full information}

One can also estimate the elasticity $\sigma$ from the equation for returns to experience or the full system of equations (table 17) :

$$
\begin{aligned}
& \frac{d w_{E}}{w_{E}}=\alpha_{E E} \cdot \frac{d \bar{E}}{\bar{E}}+1 / \sigma \frac{\bar{X} \cdot F_{X}}{F} \cdot \frac{d \bar{X}}{\bar{X}}+C \\
& \frac{d w_{X}}{w_{X}}=\alpha_{X X} \cdot \frac{d \bar{X}}{\bar{X}}+1 / \sigma \cdot \frac{\bar{E} \cdot F_{E}}{F} \cdot \frac{d \bar{E}}{\bar{E}}+C^{\prime}
\end{aligned}
$$

In table 16, one can see that the elasticity estimated using the regional panel is slightly higher 
(0.45) with the linear specification and around 0.37 with the $5 \mathrm{D}$ specification. In each case, $\eta$ is found to be lower, around $8 \%$, even if given larger SD with this set of estimates, one is still in the confidence interval of the previous estimates. One can remark that the coefficients of experience and education have the expected sign (positive for education, negative for experience). It is also remarkable to see that in all specifications, the trend in returns to experience is not significant or even negative, implying that a proper accounting of the supply of experience leads to conclude to the absence of biased technical progress with respects to the demand for experience. One could have had this prior given that technical progress in the last decades was probably in favor of those workers comfortable with new technologies, i.e. younger workers.

One can finally use the full information about the system. Table 17 summarizes the information (spec. lin), either using constrained estimates (rows WLS or WLS $\backslash 12$ ) or estimating $1 / \sigma$ and its SD as a weighted (by the precision) average of the two estimates taken independently; the advantage of this formula is that one can introduce in each independent regression the autoregressive errors and control for cross-sectional heteroskedasticity. This is why in the constrained estimates (WLS \12) dropping the outlier (unit 12) modifies the results. Here again, the value of $\sigma$ are in a range 0.26 to 0.44 . The implied value of $\eta$ is between $9 \%$ and $15 \%$ with the linear specification, close to the previous unconstrained estimates. Similar (unreported) results were obtained when using the $5 D$ specification.

\section{Conclusion}

This paper has relaxed a central assumption in the studies of the wage distribution in the US: that is, that some labor inputs do not compete with each other. In contrast, the assumption here is that all workers supply their skills on the same labor market. For that, a measure of efficient units of experience and education has been proposed, which makes it possible to analyze jointly the consequences of rising female participation and the variations in the size of the cohorts of new 
entrants to the labor market.

According to this measure of skills, it appears that the historical changes of the skills composition of labor supply is not an unambiguous rise in the level of these skills, but rather a compositional change, from high experience / low education workers to low experience / high education workers, with a tendency in the late 80's towards an increase in experience again. It follows that the rising returns to experience observed in the US and in France are explained by pure supply factors. In the US, no trend in returns to experience is found.

Another result of the paper is that in the US., the higher demand for education can be linked, to a large extent, to changes in the experience levels : given some complementarity between experience and education, the increased supply of experience lead to a rise in the demand for education in the 80's. The assumptions on returns to scale and the share of experience in production only affect the estimated elasticity of substitution, roughly $1 / 5$ to $1 / 3$. However, these assumptions are neutral in terms of what can be explained about the demand for education.

This leads to partly challenge the conventional wisdom about the trend in inequality, even though, in most of the specifications, a positive trend in the demand for education remains. Indeed, for US. male workers, the college/high school premium was $30 \%$ in the 60 's, it declined to $25 \%$ in the mid 70's and rose up to $35 \%$ in the late 90 's ; according to section 4, the contribution of experience explained here represent about 1.5 percentage points of the post-1980 increase in the college premium. With the linear specification, returns to schooling were $8.1 \%$ in the 60 's, $7.5 \%$ in the 70 's and rose to more than $12 \%$ in the late 90 's. One can attribute 0.45 to 0.68 percentage point (up to 0.90 if $\lambda=1$ ) of the rising returns to schooling in the period 1980-99 to the variations in experience. In other words, the new supply factors introduced in this paper cannot fully eliminate the trend. However, since this trend still remains a mystery, reducing its importance is a valuable contribution. 
A recent paper by Beaudry and Green (2000) also involves provocatively the role of labor force growth in the widening of the US wage distribution, compared to Germany for instance where such supply changes did not take place : in their paper, the decline in the price of technologies seems a prima facie to play the same role as our revealed changes in the supply of experience. To some extent, our comparison of France and the US, showing notably that, contrary to the US., returns to education decreased in France, could also indicate that higher demand for education interacts tightly with demographic changes : those changes were indeed slower in France. Investigation of other countries along these lines would bring many new insights about the past decades' impressive evolutions in the wage structure.

\section{References}

[1] Abraham, K. G. and Farber H.S. (1987). "Job Duration, Seniority, and Earnings", American Economic Review 77(3), pp278-97.

[2] Altonjji, J.G. and Shakotko R. A. (1987). "Do Wages Rise with Job Seniority", Review of Economic Studies, LIV, pp437-459.

[3] Beaudry, P. and Green D. (2000). "On the Effects of Population Growth In the Information Era: A Theory of Cross-Country Differences in Recent Economic Performance", mimeo Concordia

[4] Becker, G. (1964). Human Capital, reprinted 1975,1993

[5] Ben Porath (1967). "The Production of Human Capital and the Life-Cycle of Earnings", Journal of Political Economy, 75:352

[6] Berger, M.C. (1983). "Changes in Labor Force Composition and Male Earnings: A Production Approach", The Journal of Human Resources, XVII(2)

[7] Bertola, G. and Ichino, A. (1995). "Wage Inequality and Unemployment: United States vs. Europe", NBER Macroannuals, pp13-66

[8] Blanchflower, D., and Freeman R.B. (1992). "Unionism in the United States and Other Advanced OECD Countries", Industrial Relations, Vol 31, No1

[9] Blanchflower, D., Loveman, G. and Katz, L.F. (1993). "A Comparison of Changes in the Structure of Wages in Four OECD Countries", Center For Economic Performance Discussion Paper nb 144, May

[10] Borjas, G.J., Freeman R.B., and Katz, L.F. (1997). "How Much Do Immigration and Trade Affect Labor Maket Outcomes", Brooking Papers in Economic Activity 1997

[11] Buchinsky, M. (1994). "Changes in the U.S. wage structure 1963-87: Application of Quantile Regression Models", Econometrica 62(2), March, pp 405-58

[12] Card, D. (2000). "The Causal Effect of Education on Earnings", in Handbook of Labor Economics, Vol. 3, Ashenfelter and Card, eds.

[13] Card D., Kramarz, F. and Lemieux, T. (1995). "Changes in the Relative Structure of Wages and Employment: A Comparison of the United States, Canada and France", Canadian Journal of Economics, 32, 4, 843-877.

[14] Card D. and T. Lemieux. (1999). "Can Falling Supply Explain the Rising Return to College for Younger Men? A cohort-Based Analysis," Center for Labor Economics, Working Paper 
Series, University of California, Berkeley, March

[15] Chay, K..and Lee, D. (1997). "Changes in the Relative Wages in the 1980's: Returns to Observed and Unobserved Skills and Black-White Wage Differentials", mimeo Berkeley

[16] Davis, S.J. (1992). "Cross-Country Patterns of Change in Relative Wage", NBER Macroannuals, 239-292

[17] DiNardo, J. and Pischke, J. (1997). "The Returns to Computer Use Revisited: Have Pencils Changed the Wage Structure Too?", Quarterly Journal of Economics, 112(1), February pp 291-303.

[18] Entorf, H. and Kramarz, F. (1994). "The impact of New Technologies on Wages: Lessons from Matching Panels on Employees and on Their Firms", mimeo CREST

[19] Fortin, N.M. and Lemieux, T. (1997). "Institutional Changes and Rising Wage Inequality: Is There a Linkage?", Journal of Economic Perspectives, Spring, pp75-96

[20] Freeman, R.B. (1986). "Demand for Education", in Ashenfelter and Layard eds., Handbook of Labor Economics Vol. 1, pp357-86.

[21] Freeman, R.B. (1993). "How Much Has De-unionization contributed to the Rise in Male Earnings Inequality", in Danzinger, Sheldon and Peter Gottschalk, eds., Uneven Tides: Rising Inequality in America, New York: Russel Sage Foundation, 1993, pp133-63

[22] Freeman, R.B. (1995). "Are your Wages Set in Beijing?", Journal of Economic Perpsectives, Summer 1995, 9, pp15-32

[23] Gosling, A., Machin, S. and Meghir C. (1996). "The Changing Distribution of Male Wages in the UK", Discussion Paper 271, CEP

[24] Gottschalk, P. (1997). "Inequality, Income Growth, and Mobility: The Basic Facts", Journal of Economic Perpsectives, Spring 1997, 11, pp21-40

[25] Goux, D. and Maurin, E. (1995). "Demand for Skilled labor, Technical Changes and International Trade, The French Case, 1970-93", mimeo INSEE

[26] Goux, D. and Maurin, E. (1996). "New Technologies, International Trade and Demand for Skilled labor, The French Case, 1970-93", mimeo INSEE, june 1996

[27] Grant, J.H. and Hamermesh, D.S. (1982). "Labor Market Competition Among Youths, White Women and Others", Review of Economics and Statistics, 354-360

[28] Hamermesh, D.S. (1986). "The Demand for Labor in the Long Run", in Handbook of Labor Economics, Vol I, edited by O. Ashenfelter and R. Layard, Elsevier Science Publisher BV

[29] Hamermesh, D.S., and Grant J. (1979). "Econometric Studies of Labor-Labor Substitution and their Implications for Policy", The Journal of Human Resources, XIV(4)

[30] Johnson, G.E. (1997). "Changes in Earnings Inequality: The Role of Demand Shifts", Journal of Economic Perpsectives, Spring 1997, 11, pp41-54

[31] Juhn, C., Murphy, K. and Pierce, B. (1991). "Accounting for the Slowdown in Black-White Wage Convergence", in Workers and their Wages, M. Kosters, ed., AEI Press, Washington, D.C.

[32] Juhn, C., Murphy, K.M. and Pierce, B. (1993). "Wage Inequality and the Rise in returns to Skill", Journal of Political Economy, pp410-42

[33] Juhn, C., Murphy, K.M. and Topel, R.H. (1991). "Why has the Natural Rate Increased Over Time?", Brooking Papers on Economic Activity, pp75-126

[34] Katz, L.F., and Murphy, K. (1992). "Changes in Relative Wages, 1963-1987: Supply and Demand Factors", Quarterly Journal of Economics, February

[35] Kramarz, K. and T. Philippon (2000), " The Impact of Differential Payroll Tax Subsidies on Minimum Wage Employment" Journal of Public Economics, forthcoming. Paper presented at ECARES-CEPR workshop on the Minimum Wage, April 1999

[36] Laroque, G. and B. Salanié. (1999). "Breaking Down Married Female Non-Employment in 
France", CREST dp 99-31, and paper presented at ECARES-CEPR workshop on the Minimum Wage, April 1999

[37] Levy, F. and Murnane, R.J. (1991). "U.S. Earnings Levels and Earnings Inequality: A Review of Recent Trends and Proposed Explanations", Journal of Economic Litterature Vol XXX (September), pp1333-1381

[38] Mincer, J. (1974). Schooling, Experience, and Earnings, National Bureau of Economic Research, New York 1974

[39] Murphy, K.M. and Topel, R.H. (1987). "The Evolution of Unemployment in the United-States: 1968-1985", in Fisher S. ed., NBER Macroannuals

[40] Topel, R.H. (1994a). "Wage Inequality and Regional labor Market Performance in the US", in Toshiaki Tachibanaki, ed., Savings and Bequests, Ann Arbors University Michigan Press

[41] Topel R.H. (1994b). "Regional Labor Markets and the Determinants of Wage Inequality", American Economic Review Papers and Proceedings, 84, 17-22, May

[42] Topel R.H. (1997). "Factors Proportions and Relative Wages: The Supply-Side Determinants of Wage Inequality", Journal of Economic Perpsectives, Spring 1997, 11, pp55-74

[43] Wasmer, E. (2001). "Measuring human capital in the labor market: the supply of experience in 8 OECD countries", forthcoming in the European Economic Review Papers and Proceedings, 2001

[44] Welch F. (1979). "Effects of Cohort Size on Earnings: The Baby Boom Babies' Financial Bust", Journal of Political Economy, S65-97 
Table 1: Share of women in the labor force, source: OECD

\begin{tabular}{ccccc}
\hline \hline & USA & Europe (12) & Europe (11) & France \\
\hline 1962 & 0.327 & - & - & - \\
1968 & 0.355 & - & - & 0.345 \\
1975 & 0.391 & - & 0.350 & 0.374 \\
1982 & 0.427 & 0.373 & 0.374 & 0.405 \\
1992 & 0.451 & 0.401 & 0.410 & 0.440 \\
\hline
\end{tabular}

Table 2: Share of 25-34 y.o. in the labor force, source ILO (1990 figure = projection)

\begin{tabular}{ccccc}
\hline \hline & USA & Northern Europe & Southern Europe & Western Europe \\
\hline 1960 & 0.207 & 0.197 & 0.245 & 0.216 \\
1970 & 0.206 & 0.203 & 0.226 & 0.235 \\
1980 & 0.274 & 0.239 & 0.260 & 0.260 \\
1990 & 0.289 & 0.238 & 0.274 & 0.269 \\
\hline
\end{tabular}

Table 3: USA, position of the percentiles of female hourly wages distribution in male wage distribution

\begin{tabular}{lccccccc}
\hline \hline Percentiles of & \multicolumn{7}{c}{ Male Wages Percentiles } \\
women's wages & 1964 & 1970 & 1977 & 1985 & 1991 & 1997 & 2000 \\
\hline 10 & 4 & 4 & 5 & 6 & 6 & 6 & 7 \\
25 & 10 & 9 & 11 & 13 & 14 & 16 & 17 \\
33 & 13 & 13 & 15 & 17 & 19 & 22 & 22 \\
50 & 21 & 20 & 23 & 27 & 32 & 35 & 35 \\
66 & 29 & 31 & 31 & 37 & 44 & 49 & 50 \\
75 & 35 & 39 & 36 & 46 & 53 & 59 & 60 \\
90 & 53 & 62 & 52 & 65 & 70 & 79 & 79 \\
\hline
\end{tabular}


Table 4: France 1992, cell averages in years, men and women in the labor force

\begin{tabular}{lcccc}
\hline \hline & \multicolumn{2}{c}{ Men } & \multicolumn{2}{c}{ Women } \\
\hline Men & True Exp. & Pot. Exp. & True Exp. & Pot. Exp. \\
All & 20.7 & 22.9 & 17.8 & 21.4 \\
exp $\leq 10$ & 5.9 & 6.6 & 5.3 & 6.4 \\
$11 \leq \exp \leq 20$ & 14.0 & 15.5 & 13.4 & 15.6 \\
$21 \leq \exp \leq 30$ & 23.3 & 25.2 & 21.9 & 25.3 \\
exp $\geq 31$ & 33.2 & 34.4 & 29.7 & 37.9 \\
Quartile 1 & 18.0 & 20.6 & 18.6 & 22.6 \\
Quartile 2 & 20.3 & 22.2 & 17.4 & 20.6 \\
Quartile 3 & 22.3 & 23.8 & 18.5 & 20.5 \\
Quartile 4 & 22.0 & 23.5 & 20.0 & 22.0 \\
\hline
\end{tabular}

Table 5: France 1992, wage return to experience and comparison experience / education (weighted SD in parentheses)

\begin{tabular}{lcc}
\hline \hline & Men & Women \\
\hline Coefficient on Experience & $0.049(0.002)$ & $0.030(0.004)$ \\
Coefficient on Experience sq. (x100) & $-0.078(0.005)$ & $-0.042(0.010)$ \\
Average returns to exp in \% (10 yrs) & 4.12 & 2.58 \\
Average returns to exp in \% (20 yrs) & 3.34 & 2.16 \\
Average returns to exp in \% (30 yrs) & 2.56 & 1.74 \\
Average returns to exp in \% (40 yrs) & 1.78 & 1.32 \\
\hline
\end{tabular}

Table 6: US: average age, potential experience and schooling of male workers in the labor force (Source: tabulations from the March CPS)

\begin{tabular}{lccc}
\hline \hline & Age & Potential Experience & Schooling \\
\hline 1965 & 38.3 & 22.3 & 11.0 \\
1970 & 36.4 & 20.0 & 11.5 \\
1975 & 35.5 & 18.5 & 11.9 \\
1980 & 34.9 & 17.6 & 12.3 \\
1985 & 35.1 & 17.5 & 12.6 \\
1990 & 37.2 & 19.3 & 12.9 \\
1995 & 37.9 & 20.1 & 13.1 \\
2000 & 38.6 & 20.6 & 13.0 \\
\hline
\end{tabular}


Table 7: US, decomposition of wages on education (E) and experience (X) (family weights and weight for hours worked; SD across the population in parentheses)

\begin{tabular}{llll}
\hline \hline Efficient Units of Education & \multicolumn{3}{c}{$\alpha_{T}$ estimated at } \\
Average in the Labor Force & $\mathrm{T}=1964$ & $\mathrm{~T}=1980$ & $\mathrm{~T}=1991$ \\
\hline $1964: \alpha_{T} \cdot<E_{i}>$ & $0.212(0.21)$ & $0.204(0.21)$ & $0.235(0.25)$ \\
$1970: \alpha_{T} \cdot<E_{i}>$ & $0.246(0.21)$ & $0.228(0.21)$ & $0.272(0.26)$ \\
$1977: \alpha_{T} \cdot<E_{i}>$ & $0.291(0.21)$ & $0.270(0.21)$ & $0.326(0.26)$ \\
$1985: \alpha_{T} \cdot<E_{i}>$ & $0.334(0.20)$ & $0.310(0.20)$ & $0.379(0.26)$ \\
$1993: \alpha_{T} \cdot<E_{i}>$ & $0.351(0.20)$ & $0.332(0.20)$ & $0.400(0.26)$ \\
$1997: \alpha_{T} \cdot<E_{i}>$ & $0.361(0.20)$ & $0.341(0.19)$ & $0.412(0.26)$. \\
$2000: \alpha_{T} \cdot<E_{i}>$ & $0.364(0.20)$ & $0.354(0.20)$ & $0.418(0.25)$ \\
\hline & \multicolumn{3}{c}{$\beta_{T}$ estimated at } \\
\hline \hline Efficient Units of Experience & $\mathrm{T}=1964$ & $\mathrm{~T}=1980$ & $\mathrm{~T}=1991$ \\
Average in the Labor Force & $0.480(0.24)$ & $0.500(0.28)$ & $0.507(0.26)$ \\
\hline $1964: \beta_{T} \cdot<X_{i}>$ & $0.451(0.25)$ & $0.462(0.29)$ & $0.478(0.26)$ \\
$1970: \beta_{T} \cdot<X_{i}>$ & $0.413(0.25)$ & $0.420(0.28)$ & $0.439(0.26)$ \\
$1977: \beta_{T} \cdot<X_{i}>$ & $0.414(0.24)$ & $0.419(0.27)$ & $0.441(0.25)$ \\
$1985: \beta_{T} \cdot<X_{i}>$ & $0.426(0.23)$ & $0.447(0.27)$ & $0.455(0.24)$ \\
$1991: \beta_{T} \cdot<X_{i}>$ & $0.443(0.23)$ & $0.464(0.26)$ & $0.472(0.23)$ \\
$1997: \beta_{T} \cdot<X_{i}>$ & $0.450(0.24)$ & $0.473(0.28)$ & $0.480(0.24)$ \\
$2000: \beta_{T} \cdot<X_{i}>$ & &
\end{tabular}

Table 8: France, decomposition of wages on education (E) and experience (X) (SD across population in parentheses)

\begin{tabular}{lll}
\hline \hline Efficient Units of Education & \multicolumn{2}{c}{$\alpha_{T}$ estimated at } \\
Average in the Employed Population & $\mathrm{T}=1970$ & $\mathrm{~T}=1993$ \\
\hline $1970: \alpha_{T} \cdot<E_{i}>$ & $0.266(0.26)$ & $0.157(0.17)$ \\
$1977: \alpha_{T} \cdot<E_{i}>$ & $0.324(0.29)$ & $0.194(0.20)$ \\
$1985: \alpha_{T} \cdot\left\langle E_{i}>\right.$ & $0.365(0.31)$ & $0.225(0.22)$ \\
$1993: \alpha_{T} \cdot\left\langle E_{i}>\right.$ & $0.422(0.35)$ & $0.270(0.25)$ \\
\hline
\end{tabular}

\begin{tabular}{lll}
\hline \hline Efficient Units of Experience & \multicolumn{2}{c}{$\beta_{T}$ estimated at } \\
Average in the Employed Population & $\mathrm{T}=1970$ & $\mathrm{~T}=1993$ \\
\hline $1970: \beta_{T} \cdot\left\langle X_{i}\right\rangle$ & $0.342(0.20)$ & $0.503(0.19)$ \\
$1977: \beta_{T} \cdot\left\langle X_{i}\right\rangle$ & $0.325(0.20)$ & $0.483(0.19)$ \\
$1985: \beta_{T} \cdot\left\langle X_{i}\right\rangle$ & $0.320(0.19)$ & $0.480(0.18)$ \\
$1993: \beta_{T} \cdot\left\langle X_{i}\right\rangle$ & $0.320(0.19)$ & $0.486(0.19)$ \\
\hline
\end{tabular}

Table 9: France 1992, Correlations between education and the error term in experience. SD across population in parentheses

\begin{tabular}{ccc}
\hline \hline & Men & Women \\
\hline Educ1 & $0.270(0.0)$ & $0.308(0.0)$ \\
Educ2 & $-0.144(0.0)$ & $-0.085(0.0)$ \\
Educ3 & $-0.030(0.03)$ & $-0.107(0.0)$ \\
Educ4 & $-0.120(0.0)$ & $-0.157(0.0)$ \\
\hline
\end{tabular}


Table 10: France 1992, Wage Equations, comparison true experience / potential experience (weighted SD in parentheses)

\begin{tabular}{lcccc}
\hline \hline & Men & \multicolumn{3}{c}{ Women } \\
\hline & (I): True Exp. & (II): Pot. Exp. & (I): True Exp. & (II): Pot. Exp. \\
Educ2 & $0.20(0.03)$ & $0.20(0.03)$ & $0.29(0.04)$ & $0.29(0.04)$ \\
Educ3 & $0.36(0.06)$ & $0.37(0.06)$ & $0.46(0.04)$ & $0.46(0.06)$ \\
Educ4 & $0.79(0.04)$ & $0.82(0.36)$ & $0.75(0.04)$ & $0.77(0.06)$ \\
exp & $0.050(0.01)$ & $0.051(0.01)$ & $0.030(0.005)$ & $0.032(0.005)$ \\
expsq * 100 & $-0.08(0.02)$ & $-0.08(0.02)$ & $-0.042(0.01)$ & $-0.045(0.01)$ \\
$\mathrm{R}^{2}$ & 0.33 & 0.33 & 0.21 & 0.20 \\
$\#$ obs & 3544 & 3544 & 2886 & 2886 \\
\hline
\end{tabular}

Table 11: US, share of changes in returns to schooling explained by changes in aggregate experience

\begin{tabular}{lc|cc|cccc}
\hline \hline Time Period & $1964-2000$ & $1964-80$ & $\mathbf{1 9 8 0 - 2 0 0 0}$ & $1964-70$ & $1970-80$ & $\mathbf{1 9 8 0 - 9 0}$ & $\mathbf{1 9 9 0 - 2 0 0 0}$ \\
\hline$d \ln w_{E}(5 D)$ & +0.56 & +0.10 & $\mathbf{+ 0 . 6 4}$ & +0.01 & -0.09 & $\mathbf{+ 0 . 3 7}$ & $\mathbf{+ 0 . 2 7}$ \\
$d \ln w_{E}($ lin $)$ & +0.52 & +0.01 & $\mathbf{+ 0 . 5 1}$ & -0.06 & +0.07 & $\mathbf{+ 0 . 2 5}$ & $\mathbf{+ 0 . 2 6}$ \\
$\frac{d \bar{X}}{\bar{X}}($ lin $)$ & -0.08 & -0.18 & $\mathbf{+ 0 . 1 0}$ & -0.07 & -0.11 & $\mathbf{+ 0 . 0 5}$ & $\mathbf{+ 0 . 0 5}$ \\
\hline Share $\eta$ if $\sigma=-1$ & 0.03 & 2.57 & $\mathbf{- 0 . 0 5}$ & -0.23 & 0.31 & $\mathbf{- 0 . 0 4}$ & $\mathbf{- 0 . 0 7}$ \\
Share $\eta$ if $\sigma=-3$ & 0.01 & 0.26 & $\mathbf{- 0 . 0 1}$ & -0.08 & 0.10 & $\mathbf{- 0 . 0 1}$ & $\mathbf{- 0 . 0 1}$ \\
Share $\eta$ if $\sigma=1$ & -0.03 & -2.57 & $\mathbf{0 . 0 5}$ & 0.23 & -0.31 & $\mathbf{0 . 0 4}$ & $+\mathbf{0 . 0 7}$ \\
Share $\eta$ if $\sigma=0.33$ & -0.09 & -7.71 & $\mathbf{0 . 1 3}$ & 0.70 & -0.94 & $\mathbf{0 . 1 2}$ & $\mathbf{0 . 1 1}$ \\
Share $\eta$ if $\sigma=0.2$ & -0.15 & -12.3 & $\mathbf{0 . 2 2}$ & 1.17 & -1.57 & $\mathbf{0 . 2 0}$ & $\mathbf{0 . 1 9}$ \\
Share $\eta$ if $\sigma=0.1$ & -0.31 & -25.7 & $\mathbf{0 . 4 4}$ & 2.33 & -3.14 & $\mathbf{0 . 4 0}$ & $\mathbf{0 . 3 8}$ \\
\hline
\end{tabular}

Table 12: US, impact of changes in aggregate experience on returns to education, SD in parentheses, ** and $*$ indicate the 5 and 10 significance level

\begin{tabular}{|c|c|c|c|c|c|c|c|c|c|}
\hline Endog. var. & $\overline{l n E d u_{t}}$ & $\overline{l n} \ln x p_{t}$ & $\bar{C}$ & $t r * 10^{2}$ & $A R(1)$ & $\overline{D D W}$ & $\overline{R^{2}}$ & \#obs & $\overline{\Delta \Delta \operatorname{tr}(\%)}$ \\
\hline $\ln w_{E d u_{t}}(5 D)$ & $\begin{array}{l}-2.04^{* *} \\
(1.05)\end{array}$ & - & $\begin{array}{l}-4.57^{* *} \\
(1.05)\end{array}$ & $\begin{array}{l}4.67^{* *} \\
(0.98)\end{array}$ & $\begin{array}{l}0.74^{* *} \\
(0.12)\end{array}$ & 1.35 & 0.94 & 36 & - \\
\hline $\ln w_{E d u_{t}}(5 D)$ & $\begin{array}{l}-0.46 \\
(0.97)\end{array}$ & $\begin{array}{l}1.77^{* *} \\
(1.90)\end{array}$ & $\begin{array}{l}-0.60 \\
(2.24)\end{array}$ & $\begin{array}{l}2.35^{* *} \\
(1.46)\end{array}$ & $\begin{array}{l}0.63^{* *} \\
(0.14)\end{array}$ & 1.44 & 0.95 & 36 & -67 \\
\hline $\ln w_{E d u_{t}}(\operatorname{lin})$ & $\begin{array}{l}-4.05^{* *} \\
(0.75)\end{array}$ & & $\begin{array}{l}-3.49^{* *} \\
(0.13)\end{array}$ & $\begin{array}{l}3.81^{* *} \\
(0.37)\end{array}$ & $\begin{array}{l}-0.47^{* *} \\
(0.16)\end{array}$ & 2.06 & 0.98 & 36 & - \\
\hline $\ln w_{E d u_{t}}(\operatorname{lin})$ & $\begin{array}{l}-2.42 \\
(1.81)\end{array}$ & $\begin{array}{l}0.52 \\
(0.54)\end{array}$ & $\begin{array}{l}-2.80^{* *} \\
(0.73)\end{array}$ & $\begin{array}{l}3.06^{* *} \\
(0.85)\end{array}$ & $\begin{array}{l}0.37^{* *} \\
(0.17)\end{array}$ & 2.02 & 0.98 & 36 & -22 \\
\hline
\end{tabular}


Table 13: US, impact of changes in aggregate experience on returns to education, SD in parentheses, ** and $*$ indicate the 5 and 10 significance level

\begin{tabular}{|c|c|c|c|c|c|c|c|c|c|c|}
\hline Endog. var. & 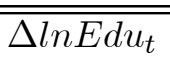 & $\overline{\overline{\Delta l n E x p_{t}}}$ & $\overline{C C * 10^{2}}$ & $\overline{A A R(1)}$ & $\overline{\overline{D D W}}$ & $\overline{R^{2}}$ & \#obs & $\overline{\Delta \Delta \operatorname{tr}(\%)}$ & $\overline{\sigma \sigma}$ & $\eta$ \\
\hline$\Delta \ln w_{E d u_{t}}(5 D)$ & $\begin{array}{l}-2.10^{* *} \\
(0.93)\end{array}$ & - & $\begin{array}{l}4.60^{* *} \\
(1.8)\end{array}$ & $\begin{array}{l}0.22 \\
(0.17)\end{array}$ & 1.95 & 0.18 & 35 & - & - & \\
\hline$\Delta \ln w_{E d u_{t}}(5 D)$ & $\begin{array}{l}-1.78 \\
(1.11)\end{array}$ & $\begin{array}{l}0.68 \\
(1.34)\end{array}$ & $\begin{array}{l}4.23^{* *} \\
(1.94)\end{array}$ & $\begin{array}{l}0.21 \\
(0.17)\end{array}$ & 1.97 & 0.19 & 35 & -8.4 & NS & NS \\
\hline$\Delta \ln w_{E d u_{t}}(\operatorname{lin})$ & $\begin{array}{l}-3.20^{* *} \\
(1.46)\end{array}$ & - & $\begin{array}{l}2.84^{* *} \\
(0.88)\end{array}$ & $\begin{array}{l}-0.12^{* *} \\
(0.18)\end{array}$ & 1.91 & 0.47 & 35 & - & & \\
\hline$\Delta \ln w_{E d u_{t}}(\operatorname{lin})$ & $\begin{array}{l}-3.80^{*} \\
(2.08)\end{array}$ & $\begin{array}{l}-0.27 \\
(0.68)\end{array}$ & $\begin{array}{l}3.08^{* *} \\
(1.07)\end{array}$ & $\begin{array}{l}-0.11 \\
(0.19)\end{array}$ & 1.92 & 0.47 & 35 & +8.1 & NS & NS \\
\hline
\end{tabular}

Table 14: Panel estimates, 21 US geographical units, impact of changes in aggregate experience on returns to education, SD in parentheses, ${ }^{* *}$ and ${ }^{*}$ indicate the 5 and 10 significance level, cross-section weights (2 stage)

\begin{tabular}{llllllllll}
\hline \hline Endog. var. & $\ln E d u_{t}$ & $\ln E x p_{t}$ & $\mathrm{FE}$ & $\operatorname{tr} * 10^{2}$ & $A R(1)$ & $D W$ & $R^{2}$ & \#obs & $\Delta \operatorname{tr}(\%)$ \\
\hline $\ln w_{E d u_{t}}(\operatorname{lin})$ & $\begin{array}{l}2.14^{* *} \\
(0.20)\end{array}$ & - & yes & $\begin{array}{l}3.09^{* *} \\
(0.12)\end{array}$ & yes & 1.97 & 0.97 & 756 & \\
$\ln w_{E d u_{t}}(\operatorname{lin})$ & $\begin{array}{l}-1.58^{* *} \\
(0.25)\end{array}$ & $\begin{array}{l}0.42^{* *} \\
(0.12)\end{array}$ & yes & $\begin{array}{l}2.78^{* *} \\
(0.14)\end{array}$ & yes & 1.95 & 0.98 & 756 & -10.6 \\
\hline $\ln w_{E d u_{t}}(5 D)$ & $\begin{array}{l}-3.13^{* *} \\
(0.40)\end{array}$ & & yes & $\begin{array}{l}3.13^{* *} \\
(0.20)\end{array}$ & yes & 1.96 & 0.83 & 751 & \\
$\ln w_{E d u_{t}}(5 D)$ & $\begin{array}{l}-1.10^{* *} \\
(0.52)\end{array}$ & $\begin{array}{l}1.25^{* *} \\
(0.20)\end{array}$ & yes & $\begin{array}{l}2.21^{* *} \\
(0.27)\end{array}$ & yes & 1.95 & 0.84 & 751 & -30.4 \\
\hline
\end{tabular}

Table 15: Panel estimates, 21 US geographical units, impact of changes in aggregate experience on returns to education, SD in parentheses, ${ }^{* *}$ and $*$ indicate the 5 and 10 significance level, cross-section weights (2 stage)

\begin{tabular}{|c|c|c|c|c|c|c|c|c|c|c|c|}
\hline Endog. var. & 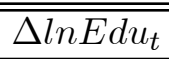 & $\Delta \overline{\Delta l n \operatorname{Exp}_{t}}$ & 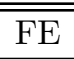 & $\mathrm{C} * 10^{2}$ & 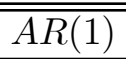 & 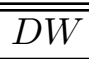 & 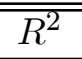 & \#obs & 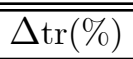 & $\overline{\sigma \sigma}$ & $\eta$ \\
\hline$\Delta \ln w_{E d u_{t}}(\operatorname{lin})$ & $\begin{array}{l}-0.16 \\
(0.45)\end{array}$ & 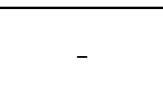 & no & $\begin{array}{l}1.75^{* *} \\
(0.37)\end{array}$ & yes & 2.17 & 0.18 & 735 & & & \\
\hline$\Delta \ln w_{E d u_{t}}(\operatorname{lin})$ & $\begin{array}{l}0.30 \\
(0.48)\end{array}$ & $\begin{array}{l}0.54^{* *} \\
(0.22)\end{array}$ & no & $\begin{array}{l}1.61^{* *} \\
(0.37)\end{array}$ & yes & 2.17 & 0.19 & 735 & -8.3 & $\begin{array}{l}0.37^{* *} \\
(0.15)\end{array}$ & 10.6 \\
\hline$\Delta \ln w_{E d u_{t}}(\operatorname{lin})$ & $\begin{array}{l}-0.03 \\
(0.47)\end{array}$ & - & yes & - & yes & 2.17 & 0.19 & 735 & & & \\
\hline$\Delta \ln w_{E d u_{t}}(\operatorname{lin})$ & $\begin{array}{l}0.47 \\
(0.49)\end{array}$ & $\begin{array}{l}0.56^{* *} \\
(0.23)\end{array}$ & yes & - & yes & 2.18 & 0.20 & 735 & -2.9 & $\begin{array}{l}0.36^{* *} \\
(0.15)\end{array}$ & 10.9 \\
\hline$\Delta \ln w_{E d u_{t}}(5 \mathrm{D})$ & $\begin{array}{l}-0.29 \\
(0.87)\end{array}$ & & no & $\begin{array}{l}1.57^{*} \\
(0.69)\end{array}$ & yes & 2.18 & 0.17 & 728 & & & \\
\hline$\Delta \ln w_{E d u_{t}}(5 \mathrm{D})$ & $\begin{array}{l}0.54 \\
(0.92)\end{array}$ & $\begin{array}{l}1.00^{* *} \\
(0.41)\end{array}$ & no & $\begin{array}{l}1.33^{* *} \\
(0.68)\end{array}$ & yes & 2.18 & 0.18 & 728 & -17.1 & $\begin{array}{l}0.20^{* *} \\
(0.08)\end{array}$ & 14.7 \\
\hline$\Delta \ln w_{E d u_{t}}(5 \mathrm{D})$ & $\begin{array}{l}-0.21 \\
(0.90)\end{array}$ & & yes & & yes & 2.19 & 0.18 & 728 & & & \\
\hline$\Delta \ln w_{E d u_{t}}(5 \mathrm{D})$ & $\begin{array}{l}0.67 \\
(0.95)\end{array}$ & $\begin{array}{l}1.03^{* *} \\
(0.42)\end{array}$ & yes & & yes & 2.19 & 0.19 & 728 & -20.3 & $\begin{array}{l}0.19^{* *} \\
(0.08)\end{array}$ & 15.2 \\
\hline
\end{tabular}


Table 16: US and panel estimates of returns to experience and implied trend, SD in parentheses, ** and * indicate the 5 and 10 significance level

\begin{tabular}{|c|c|c|c|c|c|c|c|c|c|c|}
\hline Endog. var. & 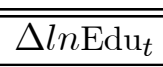 & $\overline{\Delta-\ln \operatorname{Exp}_{t}}$ & $\overline{\mathrm{FE}}$ & $\bar{C} C * 10^{2}$ & 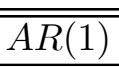 & $\overline{D D W}$ & $\overline{R^{2}}$ & \#obs & $\sigma$ & $\eta$ \\
\hline$\Delta \ln w_{\operatorname{Exp}}(\operatorname{lin})$ & $\begin{array}{l}0.67 \\
(0.56)\end{array}$ & $\begin{array}{c}-0.40^{*} \\
(0.24)\end{array}$ & no & $\begin{array}{l}0.15 \\
(0.40)\end{array}$ & yes & 2.06 & 0.16 & 735 & $\begin{array}{l}0.45^{*} \\
(0.37)\end{array}$ & 8.7 \\
\hline \multirow[t]{2}{*}{$\Delta \ln w_{\operatorname{Exp}}(5 \mathrm{D})$} & $\begin{array}{l}0.81 \\
(0.23)\end{array}$ & $\begin{array}{l}-0.23 \\
(0.24)\end{array}$ & no & $\begin{array}{l}0.01 \\
(0.4)\end{array}$ & yes & 2.05 & 0.16 & 735 & $\begin{array}{l}0.37^{*} \\
(0.26)\end{array}$ & 8.0 \\
\hline & $\ln E d u_{t}$ & $\ln \operatorname{Exp}_{t}$ & & $t r * 10^{2}$ & & & & & & \\
\hline $\ln w_{E x p_{t}}(\operatorname{lin})$ & $\begin{array}{l}1.86^{* *} \\
(0.18)\end{array}$ & $\begin{array}{l}-1.10^{* *} \\
(0.13)\end{array}$ & no & $\begin{array}{l}-0.31^{* *} \\
(0.10)\end{array}$ & yes & 2.04 & 0.99 & 756 & & \\
\hline $\ln w_{E x p_{t}}(5 \mathrm{D})$ & $\begin{array}{l}1.79^{* *} \\
(0.18)\end{array}$ & $\begin{array}{l}-0.92^{* *} \\
(0.13)\end{array}$ & yes & $\begin{array}{l}-0.36 \\
(0.10)\end{array}$ & yes & 2.04 & 0.99 & 756 & & \\
\hline
\end{tabular}

Table 17: US and panel estimates of a system of equations : returns to education and returns to experience, SD in parentheses, ${ }^{* *}$ and ${ }^{*}$ indicate the 5 and 10 significance level

\begin{tabular}{|c|c|c|c|c|c|c|c|c|c|c|}
\hline Endog. var. & $1 / \sigma$ & $\mathrm{FE}$ & $\mathrm{AR}(1)$ & Method & Constrained & \#obs & Wald & $p$ & $\sigma$ & 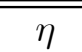 \\
\hline$\Delta \ln w_{E d u_{t}}$ & $\begin{array}{l}2.64^{*} \\
(1.67)\end{array}$ & yes & no & WLS & yes & 1512 & 2.88 & 0.09 & $\begin{array}{l}0.38^{*} \\
(0.24)\end{array}$ & 10.3 \\
\hline$\Delta \ln w_{E d u_{t}}$ & $\begin{array}{l}3.79^{* *} \\
(1.67)\end{array}$ & yes & no & WLS \st12 & yes & 1440 & 1.84 & 0.17 & $\begin{array}{l}0.26^{* *} \\
(0.12)\end{array}$ & 15.0 \\
\hline$\Delta \ln w_{E d u_{t}}$ & $\begin{array}{l}2.29^{*} \\
(2.44)\end{array}$ & yes & no & Average OLS & no & 1512 & 3.64 & 0.05 & $\begin{array}{l}0.44^{*} \\
(0.47)\end{array}$ & 8.9 \\
\hline$\Delta \ln w_{E d u_{t}}$ & $\begin{array}{l}2.68^{* *} \\
(2.25)\end{array}$ & yes & yes & Average OLS & no & 1470 & 0.22 & 0.37 & $\begin{array}{l}0.37 \\
(0.31)\end{array}$ & 10.6 \\
\hline
\end{tabular}




\section{Appendices}

\section{Appendix 1. Description of the US dataset}

US CPS: 1964-1997

Data

I use the March Current Population Survey on the subset of the 16-65 aged population. The year 1962 and 63 were recently made available, but their quality was not sufficient to undertake the same estimations as for the subsequent years. I first describe the variables and their transformation by the software provided with the data. The weights used are the family weights (famwgt). In the sections where what matters is the supply of hours, this weight is multiplied by the hours worked. The five education groups correspond to: less than 12, 12, 13-14, 15-16 and more than 17 years of schooling. As usual, experience is actually measured as potential experience Max (age-education-5, 0). The variable _educ denotes the number of years of schooling, and was build from the variables grdhi (highest grade attended) and grdcom (Did ... finished this grade?). After 1992, those two variables are not available, and I used the variable grdatn (educational attainment). The inconsistency in the definition of _educ seems however small. The weekly wage is given by the variable _wklywg (average weekly earnings last year). It is defined as incwage/_wkslyr where incwage measures the income from wage and salary and _wkslyr measures the imputed usual weeks worked last year. The variable _wkslyr is imputed on the basis of the variable wkslyr whose modalities are $0,1-13,14-26,27-39$ and more than 39 before 1976 and continuous after 1976). The employment status is given by the variable _esr which is a recode of the variables esr and _wkslyr (weekly wage) over the 1964-94 period, whose modalities are: Not in the universe, employed working, employed not working, unemployed and not in the labor force. The variable $f t p t$ describes the full-time full-year status (more than 50 weeks last year, usually more than 35 hours per week) i.e. four occurrences plus a non-worker and an invalid status. The variable hours gives the hours worked last week and the variables hrs35 and hrs35b indicate whether or not the interviewed worked usually more are less than 35 hours last week. The hours worked per week last year are measured by hrslyr, but are available since 1976 only.

Hourly wage

I describe the chosen definition of the hourly wages: after 1976, I define lhw $=\log \left(\_w k s l y r / h r s l y r\right)$. Before 1976, information is only available on full-time / part-time, and the hours worked last week (bracketed, modalities 1-4, 5-14, 15-29 and 30-34). Before 1977, when the number of hours worked last week is consistent with the part-time / full-time status, the imputed number of hours is the number of hours worked last week. When it is not, we give the conditional mean of hours worked in average given the part-time full-time status ( 45 hours for a full-time, 20 hours for a part-time). Further work is needed to improve the imputation method.

\section{Top-coding}

As well known, the variable incwage is top-coded at $\$ 99999$ between 1964 and 1967 , at $\$ 50000$ between 1968 and 1981, at $\$ 75000$ between 1982 and 1984, at $\$ 99999$ between 1985 and 1988 and at $\$ 199998$ between 1988B and 1995. The number of top-coded units is typically small compared to the size of the sample, except in the 70's, where this fraction has constantly increased over time. The usual method is to impute the average value of those with income larger than the top-code value assuming an exponential distribution of the log of earnings. This is equivalent to multiplying the top-coded earnings by a coefficient estimated from a year in which earnings are almost not top-coded. This value is 1.45 (see Buchinsky 1994 for instance).

Other control variables

I also added in the regressions a geographical location variable (North-East, North central / Midwest, South and West), an industry variable (Agriculture and Mining, Construction, Manufacturing, Services and Administration, and, when available, a union status variable).

Geography

The March CPS allows to construct a variable (_state) which is the state location of the household 
recoded with the lowest common denominator : there are 21 such geographical units : for instance, the code 1 groups Maine, New Hampshire, Vermont, Massachussets and Rhode Islands, 2 is Connecticut alone, 3 is New York alone, 4 is New Jersey alone, etc...

\section{Appendix 2. Description of the French datasets}

French surveys Formation et Qualifications Professionnelles: 1970, 1977, 1985, 1993

The data were provided by INSEE and by Dominique Goux. A very important work by Goux and Maurin was undertaken to match the definitions of the sample for different years. I report here the description of the data, as it appear in Goux and Maurin (1996): the survey is conducted on a sample of about 45000 individuals aged 20-65 until 1985, and 18000 in 1993. Diploma are pooled into 5 groups: No diploma, Vocational degree (CEP, CAP, BEP), Baccalauréat, DEUG and Maîtrise or more, which in order represent: 0 year of schooling, 5 to 8 years of schooling, 12 years of schooling, 14 and more than 15 years of schooling. The last two groups were pooled together given the small size of the sub-samples (experience sex). Workers declare their earnings in the year preceding the survey, the number of months of activity, and the part-time / full-time status. It is only in 1993 that the number of hours worked is available, before the part-time are treated as half-time workers in the construction of the hourly wage data. Experience is built as the difference between current age and age at the end of schooling.

Survey Actifs Financiers 1992

In the survey Actifs Financiers 1992, individuals are asked a series of questions on their past, including the age of end of schooling (variables JER201 or JEC201 for the person of reference of the household and his/her partner), the age of first paid job (variables $A R 201$ or $A C 201$ ), the number of periods of employment interruptions ( $A R 63$ or $A C 63$ ), the reason for it (unemployment, inactivity or disease, in $A R 64$ or $A C 64$ ), and finally, true employment experience as measured by the number of years in employment (defined as paid activity excluding "Petits boulots") (variables $A R 65$ and $A C 65$ ) and the number of years in full-time employment ( $A R 66$ and $A C 66$ ). This is quite unique in micro-surveys, since usually employment experience is approximated by the potential experience or Mincer's proxy (age - education - 5 or 6).

Education is defined by the highest diploma obtained in general or vocational classes, and if there is no diploma, the level reached (variables DIEG, DIEP, DIES and NIVSAN). It is defined by eight dummy variables (No Diploma, CEP, CAP or BEP, BEPC, Bac Technique, Bac Général, Deug-Licence, Maitrise and higher) which correspond in order to: 5 years of schooling, 8 years vocational, 8 years general, 12 years vocational, 12 years general, 14 years and more than 15 years. This gives a balanced partition of the sample. Annual wage earnings for 1990 includes premia and wages from temporary employment and secondary activities (variable $R E 01 b 1$ and 2 for the person of reference of the household and his/her partner). Individuals declare the number of months corresponding ( $R E 01 b 1$ and 2$)$, as well as the percentage with respect to a full-time job $(R E 01 d 1$ and 2$)$. There is no problem of top-coding here. Then the log of hourly wage is defined as $\log (R E 01 b 1 / R E 01 c 1 * R E 01 d 1 /(39 * 4))$ where 39 is the legal weekly number of hours. The sample is restricted to the 15-65 years old, not retired. About $10 \%$ of the sample whose current or last activity was self-employment are excluded, since returns to experience in this type of activity may differ from returns to paid activity. Standard data are used as instruments for endogeneity of participation of women: the number of children of age 3,6 and 18, the number of individuals in the household, the marital status, the status of head of household (1 if yes), the activity of individual's mother, the existence of an activity in the past, the year of constitution of household. To instrument true experience in wage equations, the same kind of variables were used.

\section{Appendix 3 (to section 3)}

\section{Wage Equations}

The wage equations are reported in tables 21 for the US and tables 22 for France. The estimator is a standard heteroskedasticity-consistent estimator following White (1980): the matrix $S=1 / n \Sigma\left(e_{i}^{2} \cdot x_{i} \cdot x_{i}^{\prime}\right)$ is shown to be under general conditions a consistent estimator of $\Sigma=X^{\prime} \Omega X / n$ which directly gives the variance-covariance matrix of the coefficients through $V(b)=\left(X^{\prime} X\right)^{-1} \Sigma\left(X^{\prime} X\right)$. 
Table 18: Appendix. USA, sample statistics (source CPS)

\begin{tabular}{llllllll}
\hline \hline & 1964 & 1970 & 1977 & 1985 & 1991 & 1997 & 2000 \\
\hline \# All Labor Force 16-64 & 29321 & 58131 & 70531 & 77157 & 77114 & 62915 & 60348 \\
Educ 1 & 0.451 & 0.368 & 0.272 & 0.190 & 0.157 & 0.136 & 0.136 \\
Educ 2 & 0.335 & 0.378 & 0.394 & 0.402 & 0.393 & 0.324 & 0.319 \\
Educ 3 & 0.084 & 0.106 & 0.137 & 0.163 & 0.178 & 0.282 & 0.286 \\
Educ 4 & 0.086 & 0.097 & 0.126 & 0.157 & 0.177 & 0.176 & 0.178 \\
Educ 5 & 0.043 & 0.050 & 0.069 & 0.089 & 0.096 & 0.082 & 0.081 \\
Exp & 24.4 & 22.8 & 20.0 & 19.3 & 19.9 & 19.8 & 20.7 \\
(SD Exp) & $(14.9)$ & $(15.2)$ & $(14.8)$ & $(13.6)$ & $(12.9)$ & $(11.7)$ & $(11.7)$ \\
Sex (Men 0, Women 1) & 0.35 & 0.39 & 0.42 & 0.45 & 0.46 & 0.48 & 0.47 \\
Black & 0.100 & 0.098 & 0.097 & 0.102 & 0.104 & 0.111 & 0.109 \\
Other Non-White & 0.009 & 0.010 & 0.016 & 0.028 & 0.034 & 0.045 & 0.047 \\
Full-Time & 0.791 & 0.817 & 0.784 & 0.779 & 0.795 & 0.825 & 0.836 \\
Hourly Wage & 2.38 & 3.30 & 5.16 & 8.90 & 11.3 & 14.8 & 16.0 \\
(SD Hourly Wage) & $(2.44)$ & $(2.70)$ & $(5.51)$ & $(8.07)$ & $(10.5)$ & $(20.7)$ & $(18.7)$ \\
\hline
\end{tabular}

\section{Discrimination}

I report here the decomposition of wages into experience and education in taking account of possible discrimination by gender represented by a parameter $\lambda$, as explained in section 2.2 .1 and in equation (3). With a value of $\lambda=1$, the results can be interpreted in two ways. First, in assuming that $100 \%$ of the difference in returns to skills between gender is due to pure discrimination, it provide the proper measure of the efficient units supplied by the labor in each component education and experience. Second, taking $\lambda=1$ is equivalent to neutralize the changes in the gender composition of the labor force and to observe the pure effect of the change in the age structure. For the US, it can be observed from the table 23 that different values of $\lambda$ have little impact on the measure of education of the labor force: much of the effect of different $\lambda$ is on the measure of experience of the labor force. Higher values of $\lambda$ tends to increase the estimated experience (not surprisingly since men have higher returns to experience). However, the decline in the level of experience of the labor force still holds, even if its amplitude is reduced with high values of $\lambda$. In the case of France, similar conclusion emerges. The quantity of education supplied increased in all the columns of table 24, and the quantity of experience supplied decreased between 1970 and 1977 in all cells and then remained more or less constant, except maybe in the extreme case where $\lambda=1$, where in 1993 the term $\sum_{i=1993} \alpha_{T} . X_{i}$ recover the 1970 level. 
Table 19: Appendix. France, sample statistics (source INSEE-FQP)

\begin{tabular}{lcccc}
\hline \hline & 1970 & 1977 & 1985 & 1993 \\
\hline \# All Labor Force 20-64 & 30645 & 31815 & 31361 & 13517 \\
Educ 1 & 0.350 & 0.274 & 0.233 & 0.203 \\
Educ 2 & 0.548 & 0.570 & 0.564 & 0.500 \\
Educ 3 & 0.062 & 0.089 & 0.095 & 0.131 \\
Educ 4 & 0.018 & 0.024 & 0.055 & 0.083 \\
Educ 5 & 0.023 & 0.044 & 0.053 & 0.082 \\
Exp & 23.7 & 22.0 & 20.9 & 20.8 \\
(SD Exp) & $(15.0)$ & $(14.3)$ & $(13.2)$ & $(11.8)$ \\
Sex (Men 0, Women 1) & 0.384 & 0.409 & 0.440 & 0.451 \\
Yearly Wage Equivalent & 63566 & 84489 & 89811 & 104251 \\
(SD) & $(47559)$ & $(59257)$ & $(54368)$ & $(78462)$ \\
\hline
\end{tabular}

Table 20: Appendix. France 1992, variable: Log Hourly Wage. (IV: Instr.=Pot. Exp.). (Heckman: Instr. described in the text, appendix 2).

\begin{tabular}{lll}
\hline \hline Men & GLS & IV \\
\hline Experience & $0.049(0.002)$ & $0.050(0.002)$ \\
Exp. Sq. (x100) & $-0.078(0.005)$ & $-0.081(0.005)$ \\
Educ=5 & $0.049(0.026)$ & $0.050(0.025)$ \\
Educ=8, Non Voc. & $0.309(0.024)$ & $0.307(0.024)$ \\
Educ=12, Non Voc. & $0.491(0.032)$ & $0.491(0.032)$ \\
Educ=8, Voc. & $0.184(0.020)$ & $0.183(0.021)$ \\
Educ $=12$, Voc. & $0.448(0.035)$ & $0.447(0.035)$ \\
Educ=14 & $0.654(0.029)$ & $0.652(0.029)$ \\
Educ $\geq 15$ & $0.939(0.027)$ & $0.938(0.027)$ \\
$\mathrm{R}^{2}$ & 0.356 & 0.356 \\
$\#$ obs & 3641 & 3641 \\
\hline
\end{tabular}

\begin{tabular}{|c|c|c|c|}
\hline Women & GLS & IV & Heckman \\
\hline Experience & $0.030(0.004)$ & $0.031(0.003)$ & $0.029(0.005)$ \\
\hline Exp. Sq. (x100) & $-0.042(0.010)$ & $-0.044(0.007)$ & $-0.038(0.011)$ \\
\hline $\mathrm{Educ}=5$ & $0.028(0.060)$ & $0.030(0.037)$ & $0.032(0.058)$ \\
\hline Educ $=8$, Non Voc. & $0.367(0.048)$ & $0.367(0.033)$ & $0.332(0.046)$ \\
\hline Educ $=12$, Non Voc. & $0.482(0.058)$ & $0.481(0.041)$ & $0.439(0.057)$ \\
\hline Educ $=8$, Voc. & $0.216(0.051)$ & $0.216(0.033)$ & $0.182(0.050)$ \\
\hline Educ $=12$, Voc. & $0.499(0.055)$ & $0.498(0.049)$ & $0.446(0.055)$ \\
\hline Educ $=14$ & $0.739(0.047)$ & $0.738(0.036)$ & $0.685(0.046)$ \\
\hline Educ $\geq 15$ & $0.903(0.055)$ & $0.902(0.042)$ & $0.844(0.055)$ \\
\hline Mills ratio & - & - & $-0.223(0.066)$ \\
\hline $\mathrm{R}^{2}$ & 0.239 & 0.239 & 0.251 \\
\hline \# obs & 3108 & 3108 & 2984 \\
\hline
\end{tabular}


Table 21: Appendix. USA, GLS of log of hourly wage of male (resp. female) workers on potential exp. and sq., 5 education dummies and two race dummies, selected years

\begin{tabular}{|c|c|c|c|c|c|c|c|}
\hline Men & 1964 & 1970 & 1977 & 1985 & 1991 & 1997 & 2000 \\
\hline \multirow[t]{2}{*}{ Educ 2} & 0.284 & 0.267 & 0.271 & 0.302 & 0.298 & 0.322 & 0.325 \\
\hline & $(0.013)$ & $(0.009)$ & $(0.009)$ & $(0.012)$ & $(0.012)$ & $(0.014)$ & $(0.013)$ \\
\hline \multirow[t]{2}{*}{ Educ 3} & 0.439 & 0.361 & 0.374 & 0.402 & 0.459 & 0.485 & 0.504 \\
\hline & $(0.018)$ & $(0.013)$ & $(0.012)$ & $(0.014)$ & $(0.014)$ & $(0.015)$ & $(0.014)$ \\
\hline \multirow[t]{2}{*}{ Educ 4} & 0.561 & 0.563 & 0.569 & 0.651 & 0.689 & 0.766 & 0.847 \\
\hline & $(0.018)$ & $(0.013)$ & $(0.012)$ & $(0.014)$ & $(0.014)$ & $(0.017)$ & $(0.015)$ \\
\hline \multirow[t]{2}{*}{ Educ 5} & 0.581 & 0.604 & 0.679 & 0.756 & 0.824 & 1.056 & 1.052 \\
\hline & $(0.023)$ & $(0.018)$ & $(0.015)$ & $(0.016)$ & $(0.016)$ & $(0.021)$ & $(0.020)$ \\
\hline \multirow[t]{2}{*}{ Exp } & 0.0496 & 0.0475 & 0.0581 & 0.0604 & 0.0531 & 0.048 & 0.048 \\
\hline & $(0.002)$ & $(0.001)$ & $(0.001)$ & $(0.001)$ & $(0.001)$ & $(0.001)$ & $(0.001)$ \\
\hline \multirow[t]{2}{*}{ Exp sq. (x100) } & -0.075 & -0.076 & -0.092 & -0.093 & -0.082 & -0.072 & -0.0073 \\
\hline & $(0.003)$ & $(0.002)$ & $(0.002)$ & $(0.003)$ & $(0.003)$ & $(0.004)$ & $(0.003)$ \\
\hline \# obs. & 14110 & 28636 & 32374 & 33075 & 31056 & 27736 & 29644 \\
\hline$R^{2}$ & 0.21 & 0.21 & 0.28 & 0.29 & 0.26 & 0.25 & 0.26 \\
\hline Av. returns to exp in $\%$ (20 yrs) & 3.46 & 3.23 & 3.97 & 4.12 & 3.67 & 3.36 & 3.34 \\
\hline Residual, diff. 90/10 percentile & 1.27 & 1.20 & 1.22 & 1.34 & 1.33 & 1.38 & 1.40 \\
\hline Residual, diff. $75 / 25$ percentile & 0.60 & 0.58 & 0.61 & 0.67 & 0.67 & 0.68 & 0.69 \\
\hline Women & $19 \overline{c 1964}$ & $19 \overline{c 1970}$ & 1977 & 1985 & 1991 & $19 \overline{c 1997}$ & 2000 \\
\hline \multirow[t]{2}{*}{ Educ 2} & 0.320 & 0.260 & 0.230 & 0.228 & 0.291 & 0.241 & 0.277 \\
\hline & $(0.015)$ & $(0.012)$ & $(0.012$ & $(0.013)$ & $(0.015)$ & $(0.017)$ & $(0.016)$ \\
\hline \multirow[t]{2}{*}{ Educ 3} & 0.392 & 0.379 & 0.357 & 0.397 & 0.457 & 0.434 & .0488 \\
\hline & $(0.021)$ & $(0.019)$ & $(0.015$ & $(0.015)$ & $(0.016)$ & $(0.017)$ & $(0.016)$ \\
\hline \multirow[t]{2}{*}{ Educ 4} & 0.544 & 0.590 & 0.536 & 0.590 & 0.722 & 0.756 & 0.831 \\
\hline & $(0.023)$ & $(0.018)$ & $(0.016)$ & $(0.016)$ & $(0.016)$ & $(0.019)$ & $(0.018)$ \\
\hline \multirow[t]{2}{*}{ Educ 5} & 0.808 & 0.778 & 0.766 & 0.850 & 0.934 & 1.000 & 1.059 \\
\hline & $(0.032)$ & $(0.029)$ & $(0.020)$ & $(0.017)$ & $(0.019)$ & $(0.024)$ & $(0.025)$ \\
\hline \multirow[t]{2}{*}{ Exp } & 0.0269 & 0.0233 & 0.0247 & 0.0303 & 0.0305 & 0.0327 & 0.320 \\
\hline & $(0.002)$ & $(0.001)$ & $(0.001)$ & $(0.001)$ & $(0.001)$ & $(0.001)$ & $(0.001)$ \\
\hline \multirow[t]{2}{*}{ Exp sq. (x100) } & -0.043 & -0.039 & -0.042 & -0.053 & -0.051 & -0.055 & -0.052 \\
\hline & $(0.004)$ & $(0.003)$ & $(0.003)$ & $(0.003)$ & $(0.003)$ & $(0.003)$ & $(0.003)$ \\
\hline \# obs. & 9751 & 17999 & 23144 & 28197 & 28863 & 24925 & 26142 \\
\hline$R^{2}$ & 0.13 & 0.13 & 0.13 & 0.16 & 0.19 & 0.19 & .019 \\
\hline Av. returns to exp in $\%$ (20 yrs) & 1.83 & 1.55 & 1.63 & 1.97 & 2.03 & 2.17 & 2.16 \\
\hline Residual, diff. $90 / 10$ percentile & 1.49 & 1.32 & 1.23 & 1.32 & 1.32 & 1.38 & 1.40 \\
\hline Residual, diff. $75 / 25$ percentile & 0.69 & 0.61 & 0.60 & 0.64 & 0.66 & 0.68 & 0.69 \\
\hline
\end{tabular}


Table 22: Appendix. France, GLS of log of hourly wage of male (resp. female) workers on potential exp. and sq., 4 education dummies

\begin{tabular}{|c|c|c|c|c|}
\hline Men & 1970 & 1977 & 1985 & 1993 \\
\hline \multirow[t]{2}{*}{ Educ 2} & 0.323 & 0.283 & 0.250 & 0.173 \\
\hline & $(0.010)$ & $(0.010)$ & $(0.010)$ & $(0.016)$ \\
\hline \multirow[t]{2}{*}{ Educ 3} & 0.693 & 0.632 & 0.562 & 0.407 \\
\hline & $(0.017)$ & $(0.014)$ & $(0.015)$ & $(0.029)$ \\
\hline \multirow[t]{2}{*}{ Educ 4} & 1.192 & 1.044 & 0.884 & 0.789 \\
\hline & $(0.022)$ & $(0.018)$ & $(0.016)$ & $(0.024)$ \\
\hline \multirow[t]{2}{*}{$\operatorname{Exp}$} & 0.0404 & 0.0475 & 0.0425 & 0.047 \\
\hline & $(0.002)$ & $(0.002)$ & $(0.002)$ & $(0.003)$ \\
\hline \multirow[t]{2}{*}{ Exp sq. (x100) } & -0.068 & -0.079 & -0.065 & -0.074 \\
\hline & $(0.003)$ & $(0.003)$ & $(0.003)$ & $(0.006)$ \\
\hline \# Obs & 16818 & 15534 & 14042 & 5782 \\
\hline$R^{2}$ & 0.32 & 0.40 & 0.39 & 0.30 \\
\hline Av. returns to exp in $\%$ (20 yrs) & 2.68 & 3.17 & 2.95 & 3.22 \\
\hline Residual, diff. 90/10 percentile & 1.09 & 0.93 & 0.90 & 0.97 \\
\hline Residual, diff. $75 / 25$ percentile & 0.54 & 0.46 & 0.45 & 0.48 \\
\hline Women & 1970 & $\overline{1977}$ & $\overline{1985}$ & 1993 \\
\hline \multirow[t]{2}{*}{ Educ 2} & 0.306 & 0.274 & 0.235 & 0.176 \\
\hline & $(0.029)$ & $(0.018)$ & $(0.019)$ & $(0.021)$ \\
\hline \multirow[t]{2}{*}{ Educ 3} & 0.684 & 0.613 & 0.502 & 0.421 \\
\hline & $(0.030)$ & $(0.022)$ & $(0.022)$ & $(0.024)$ \\
\hline \multirow[t]{2}{*}{ Educ 4} & 0.864 & 0.817 & 0.704 & 0.687 \\
\hline & $(0.045)$ & $(0.023)$ & $(0.022)$ & $(0.025)$ \\
\hline \multirow[t]{2}{*}{$\operatorname{Exp}$} & 0.0162 & 0.0244 & 0.0279 & 0.0360 \\
\hline & $(0.003)$ & $(0.002)$ & $(0.019)$ & $(0.003)$ \\
\hline \multirow[t]{2}{*}{ Exp sq. (x100) } & -0.033 & -0.046 & -0.047 & -0.062 \\
\hline & $(0.006)$ & $(0.004)$ & $(0.004)$ & $(0.006)$ \\
\hline \# obs & 6379 & 8878 & 9247 & 4926 \\
\hline$R^{2}$ & 0.18 & 0.21 & 0.21 & 0.21 \\
\hline Av. returns to exp in \% (20 yrs) & 0.96 & 1.52 & 1.85 & 2.36 \\
\hline Residual, diff. $90 / 10$ percentile & 1.04 & 0.86 & 0.87 & 0.95 \\
\hline Residual, diff. $75 / 25$ percentile & 0.52 & 0.41 & 0.41 & 0.44 \\
\hline
\end{tabular}


Table 23: Appendix. USA, decomposition of wages on experience and education with gender discrimination (SD in parentheses)

\begin{tabular}{|c|c|c|c|c|c|}
\hline \multirow{2}{*}{$\begin{array}{l}\text { Efficient Units of Education } \\
\text { Average in the Labor Force }\end{array}$} & \multicolumn{5}{|c|}{$\alpha_{T}$ estimated at $\mathrm{T}=1964$} \\
\hline & $\lambda=0$ & $\lambda=0.25$ & $\lambda=0.5$ & $\lambda=0.75$ & $\lambda=1$ \\
\hline $1964: \alpha_{T} \cdot<E_{i}>$ & $0.212(0.21)$ & $0.211(0.21)$ & $0.209(0.23)$ & $0.208(0.21)$ & $0.206(0.21)$ \\
\hline $1970: \alpha_{T} \cdot<E_{i}>$ & $0.246(0.21)$ & $0.244(0.21)$ & $0.242(0.21)$ & $0.240(0.21)$ & $0.239(0.20)$ \\
\hline $1977: \alpha_{T} \cdot<E_{i}>$ & $0.291(0.21)$ & $0.289(0.21)$ & $0.287(0.20)$ & $0.285(0.20)$ & $0.283(0.20)$ \\
\hline $1985: \alpha_{T} \cdot<E_{i}>$ & $0.334(0.20)$ & $0.332(0.20)$ & $0.329(0.20)$ & $0.327(0.20)$ & $0.324(0.19)$ \\
\hline $1991: \alpha_{T} \cdot<E_{i}>$ & $0.351(0.20)$ & $0.349(0.20)$ & $0.346(0.19)$ & $0.344(0.19)$ & $0.341(0.19)$ \\
\hline Efficient Units of Experience & \multicolumn{5}{|c|}{ 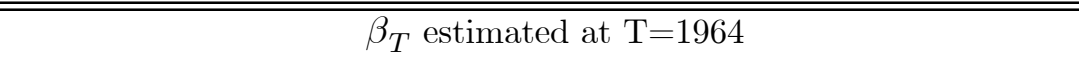 } \\
\hline Average in the Labor Force & $\lambda=0$ & $\lambda=0.25$ & $\lambda=0.50$ & $\lambda=0.75$ & $\lambda=1$ \\
\hline $1964: \beta_{T} \cdot<X_{i}>$ & $0.480(0.24)$ & $0.506(0.24)$ & $0.532(0.23)$ & $0.557(0.23)$ & $0.583(0.24)$ \\
\hline $1970: \beta_{T} \cdot<X_{i}>$ & $0.451(0.25)$ & $0.478(0.24)$ & $0.504(0.24)$ & $0.530(0.25)$ & $0.557(0.26)$ \\
\hline $1977: \beta_{T} \cdot<X_{i}>$ & $0.413(0.25)$ & $0.439(0.24)$ & $0.465(0.25)$ & $0.491(0.25)$ & $0.517(0.26)$ \\
\hline $1985: \beta_{T} \cdot<X_{i}>$ & $0.414(0.24)$ & $0.442(0.23)$ & $0.471(0.23)$ & $0.500(0.23)$ & $0.529(0.24)$ \\
\hline $1991: \beta_{T} \cdot<X_{i}>$ & $0.426(0.23)$ & $0.457(0.22)$ & $0.488(0.22)$ & $0.520(0.23)$ & $0.551(0.24)$ \\
\hline
\end{tabular}

Table 24: Appendix. France, decomposition of wages on experience and education with gender discrimination (SD in parentheses)

\begin{tabular}{llllll}
\hline \hline Efficient Units of Education & \multicolumn{5}{c}{$\alpha_{T}$ estimated at T=1970 } \\
Average in the Emp. Pop. & $\lambda=0$ & $\lambda=0.25$ & $\lambda=0.5$ & $\lambda=0.75$ & $\lambda=1$ \\
\hline $1970: \alpha_{T} \cdot<E_{i}>$ & $0.266(0.26)$ & $0.268(0.26)$ & $0.270(0.27)$ & $0.271(0.27)$ & $0.273(0.27)$ \\
$1977: \alpha_{T} \cdot<E_{i}>$ & $0.324(0.29)$ & $0.326(0.30)$ & $0.329(0.30)$ & $0.331(0.30)$ & $0.333(0.31)$ \\
$1985: \alpha_{T} \cdot<E_{i}>$ & $0.365(0.31)$ & $0.368(0.31)$ & $0.372(0.32)$ & $0.375(0.32)$ & $0.379(0.33)$ \\
$1993: \alpha_{T} \cdot<E_{i}>$ & $0.422(0.35)$ & $0.426(0.35)$ & $0.431(0.37)$ & $0.436(0.36)$ & $0.440(0.37)$ \\
\hline \hline Efficient Units of Experience & \multicolumn{5}{c}{$\beta_{T}$ estimated at T=1970 } \\
Average in the Emp. Pop. & $\lambda=0$ & $\lambda=0.25$ & $\lambda=0.50$ & $\lambda=0.75$ & $\lambda=1$ \\
\hline $1970: \beta_{T} \cdot<X_{i}>$ & $0.342(0.20)$ & $0.370(0.17)$ & $0.397(0.15)$ & $0.426(0.15)$ & $0.454(0.15)$ \\
$1977: \beta_{T} \cdot<X_{i}>$ & $0.325(0.20)$ & $0.354(0.17)$ & $0.384(0.16)$ & $0.413(0.15)$ & $0.442(0.15)$ \\
$1985: \beta_{T} \cdot<X_{i}>$ & $0.320(0.19)$ & $0.351(0.17)$ & $0.381(0.15)$ & $0.412(0.15)$ & $0.443(0.15)$ \\
$1993: \beta_{T} \cdot<X_{i}>$ & $0.320(0.19)$ & $0.353(0.17)$ & $0.386(0.15)$ & $0.419(0.15)$ & $0.452(0.15)$ \\
\hline
\end{tabular}




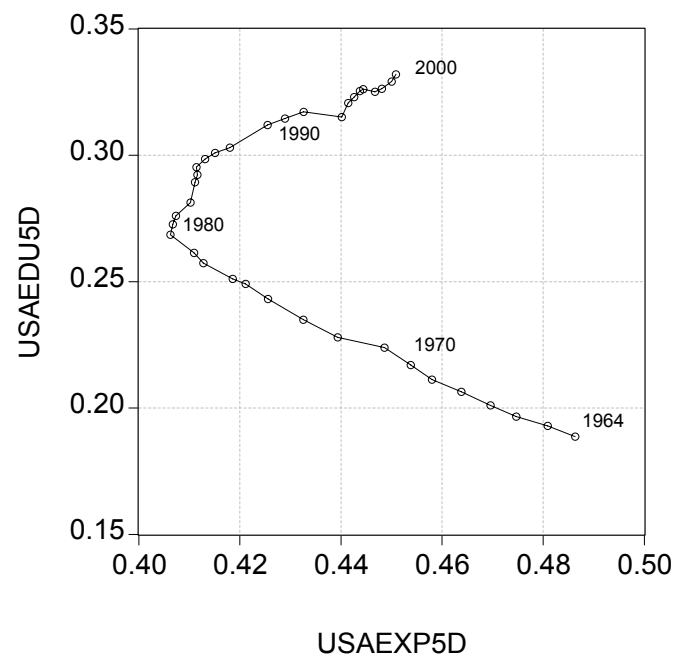

Figure 1: US. Historical Decomposition of the Skill Level of the Labor Force (X-axis: Experience; Y-axis: Education). Ref: Educ 0, Exp. 0. Specification for Education : 5 dummies. Family weights. Source CPS and author's calculations.



Figure 2: US. Historical Decomposition of the Skill Level of the Labor Force (X-axis: Experience; Y-axis: Education). Ref: Educ 0, Exp. 0. Specification for Education : 5 dummies. Controlling for gender discrimination (lambda $=1$ ). Family weights. Source CPS and author's calculations. 




Figure 3: US. Historical Decomposition of the Skill Level of the Labor Force (X-axis: Experience; Y-axis: Education). Ref: Educ 0, Exp. 0. Linear Specification for Schooling. Family weights. Source CPS and author's calculations.

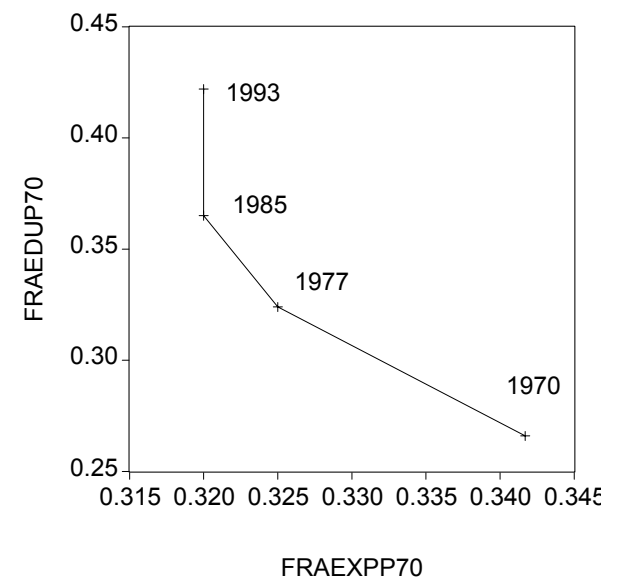

Figure 4: France. Historical Decomposition of the Skill Level of the Labor Force (X-axis: Experience; Y-axis: Education). Ref: Educ 0, Exp. 0; expressed in 1970 price. Source FQP and author's calculations. 




Figure 5: France. Historical Decomposition of the Skill Level of the Labor Force (X-axis: Experience; Y-axis: Education). Ref: Educ 0, Exp. 0; expressed in 1993 price. Source FQP and author's calculations.
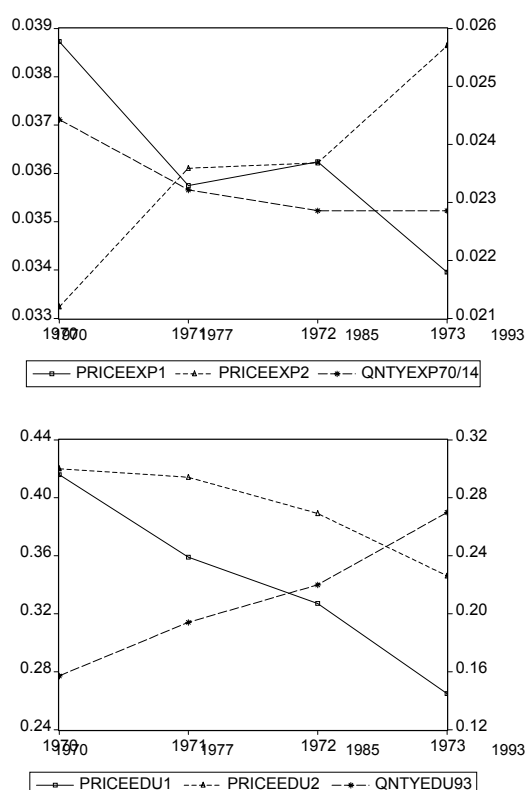

Figure 6: France. Joint Evolution of Returns to Skills and the Efficient Quantities of Skills Supplied. Top: Experience. Bottom: Education. Solid Line: Returns to Skills, entire sample; Dash Line (triangles): Returns to Skills, high wage sample. Dash Line (Square): Efficient Units Supplied. Source: FQP and author's calculations 

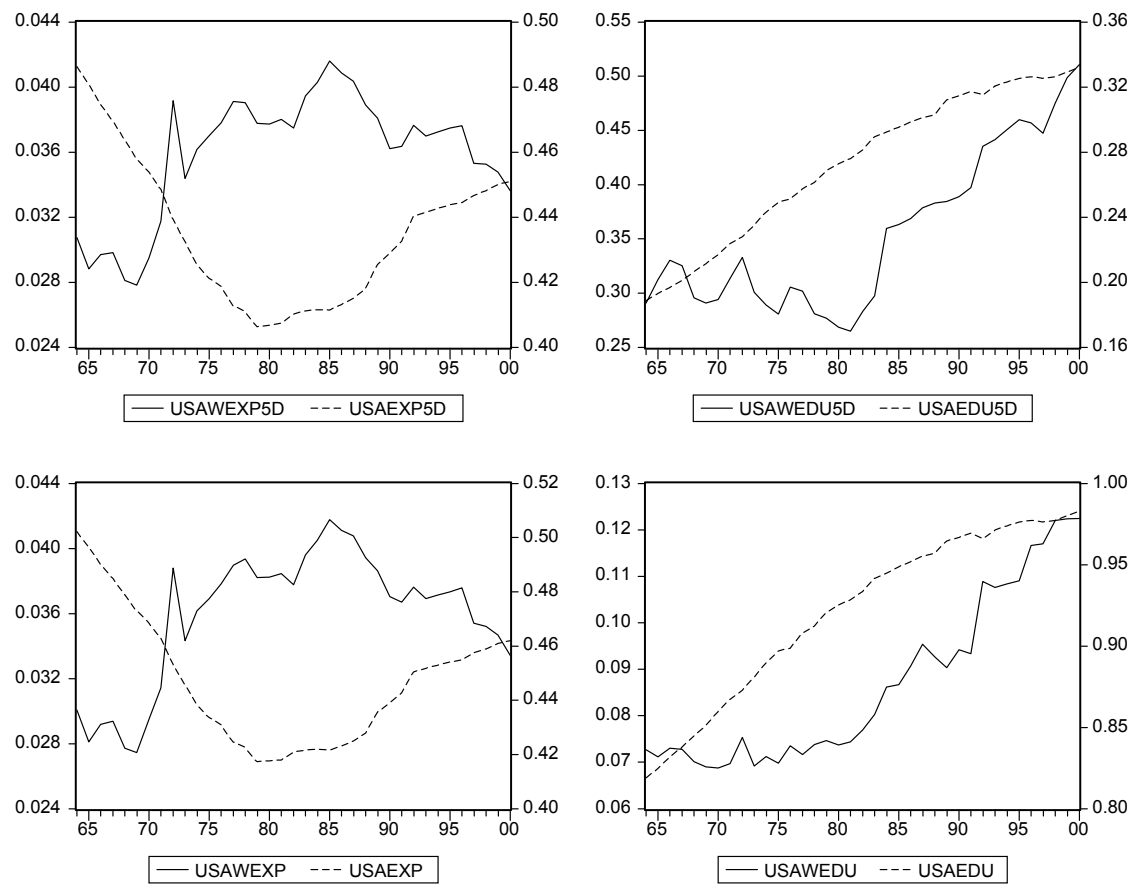

Figure 7: US. Joint Evolution of Returns to Skills and the Efficient Quantities of Skills Supplied. Top: 5 Dummies Spec for Educ. Bottom : Linear Spec for Educ. Left : Experience and returns. Right : Education and returns. Solid Line: Returns to Skills. Dash Line: Efficient Units Supplied. Source: CPS and author's calculations 

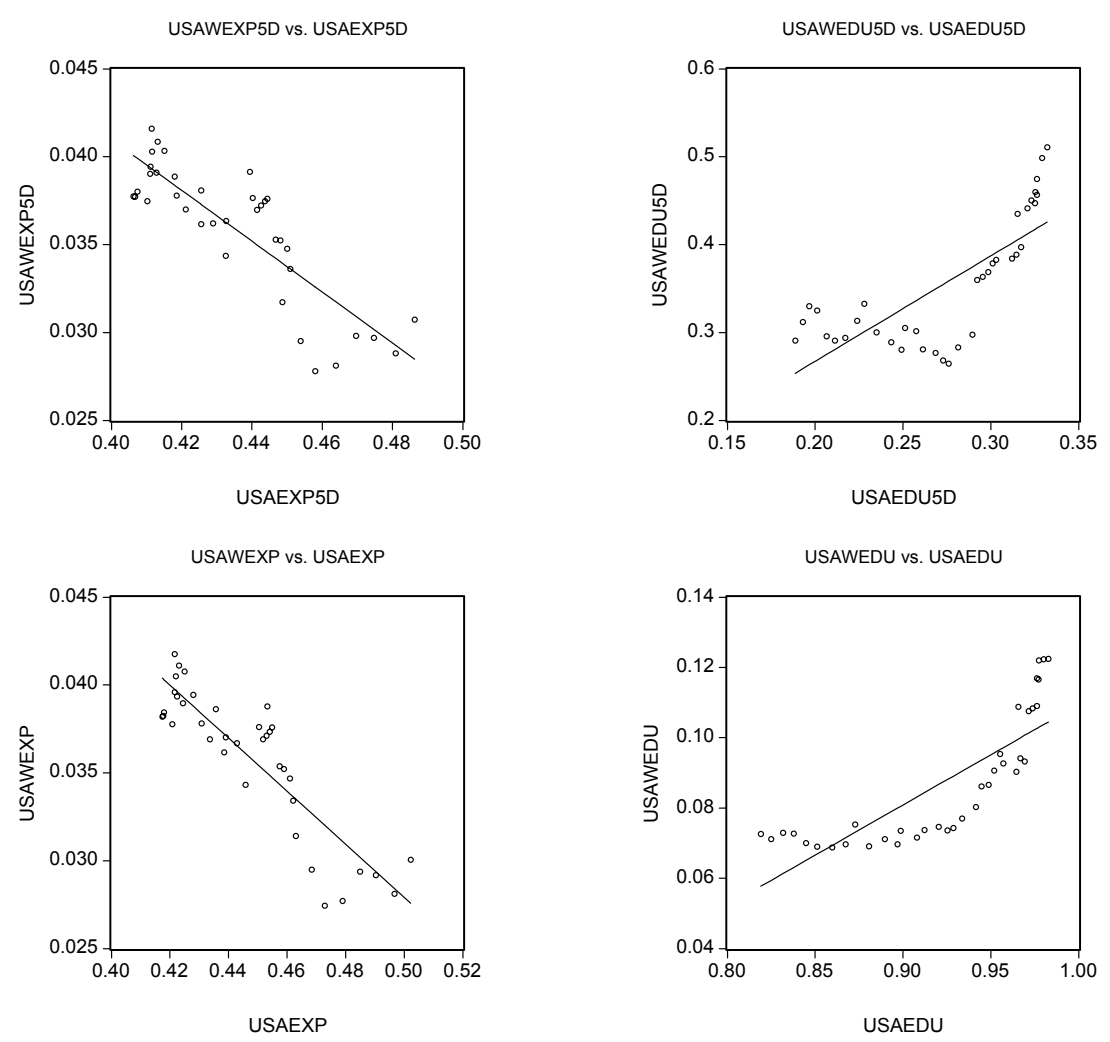

Figure 8: US. Joint Evolution of Returns to Skills and the Efficient Quantities of Skills Supplied (scatter view and regression line). Top: 5 Dummies Spec for Educ. Bottom : Linear Spec for Educ. Left : Experience and returns. Right : Education and returns. Solid Line: Returns to Skills. Dash Line: Efficient Units Supplied. Source: CPS and author's calculations 

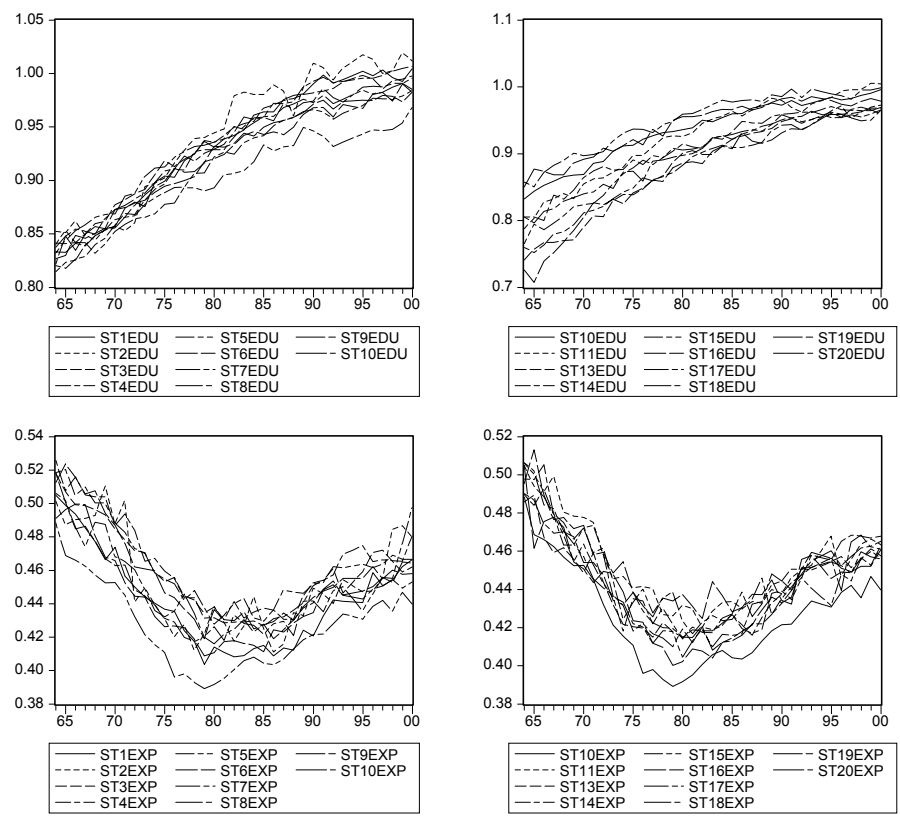

Figure 9: US : regional evolution of the supply of skills. Up : education (linear specicifcation). Down : experience. Source : CPS and author's calculations.
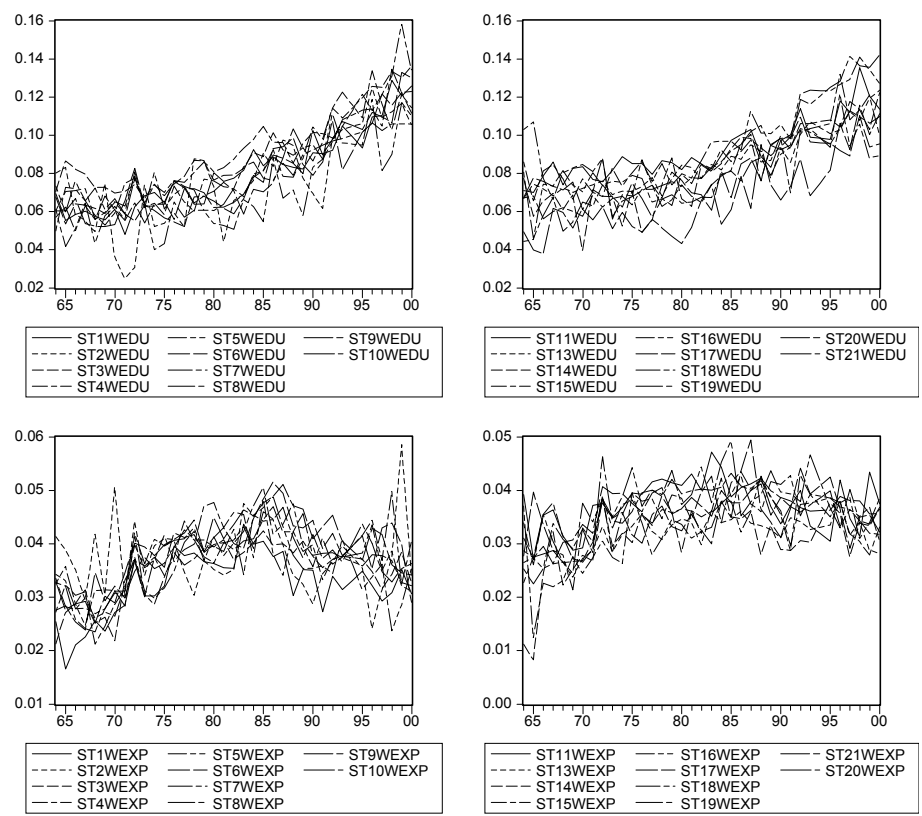

Figure 10: US : regional evolution of returns to skills, male workers. Up : returns to schooling (linear specification). Down : average returns to 20 years of experience. Source : CPS and author's calculations. 

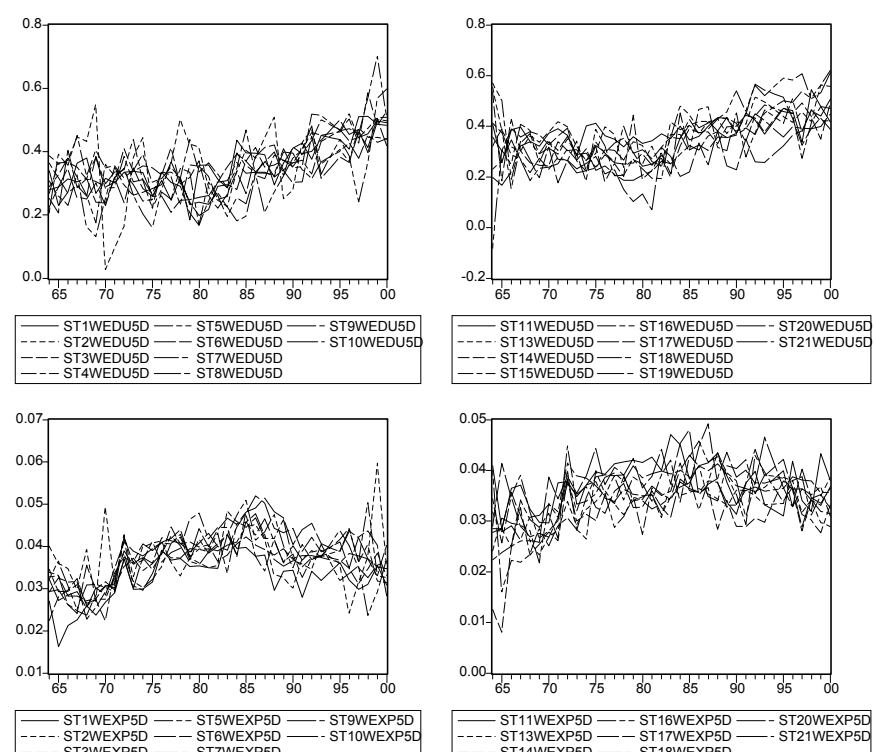

- ST11WEXP5D --- ST16WEXP5D - ST20WEXP5

- STISWEXP5D 二- STTWEXP5

-- ST14WEXP5D - - ST18WEXP5D
--- ST15WEXP5D - ST19WEXP5D

Figure 11: US : regional evolution of returns to skills, male workers. Up : returns to schooling (5D specification). Down : average returns to 20 years of experience. Source : CPS and author's calculations. 


\section{IZA Discussion Papers}

\section{No Author(s)}

211 A. van Soest M. Das

X. Gong

212 X. Gong

A. van Soest

P. Zhang

213 X. Gong

A. van Soest

E. Villagomez

214 X. Gong

A. van Soest

215 J. Ermisch

M. Francesconi

216 F. Büchel

217 J. Hansen

R. Wahlberg

218 C. Dustmann

A. van Soest

219 F. Kramarz

T. Philippon

220 W. A. Cornelius

E. A. Marcelli

221

C. Grund

222 W.P.M. Vijverberg

223 M. Rosholm

M. Svarer

224 J. Schwarze
Titel

Area

Date

A Structural Labour Supply Model with Nonparametric Preferences

5

$11 / 00$

Sexual Bias and Household Consumption: A

5

$11 / 00$

Semiparametric Analysis of Engel Curves in Rural

China

Mobility in the Urban Labor Market: A Panel Data

1

Analysis for Mexico

$11 / 00$

Family Structure and Female Labour Supply in

5

$11 / 00$

Mexico City

The Effect of Parents' Employment on Children's

Educational Attainment

5

$11 / 00$

The Effects of Overeducation on Productivity in

5

$11 / 00$

Germany - The Firms' Viewpoint

Occupational Gender Composition and

5

$11 / 00$

Wages in Sweden

Parametric and Semiparametric Estimation in

1

$11 / 00$

Models with Misclassified Categorical Dependent

Variables

The Impact of Differential Payroll Tax Subsidies

on Minimum Wage Employment

5

$11 / 00$

The Changing Profile of Mexican Migrants to the

United States: New Evidence from California and

1

$12 / 00$

Mexico

Wages as Risk Compensation in Germany

5

$12 / 00$

Betit: A Family That Nests Probit and Logit

$12 / 00$

Wages, Training, and Job Turnover in a Search-

Matching Model

7

$12 / 00$

Using Panel Data on Income Satisfaction to

Estimate the Equivalence Scale Elasticity 
On the Identification of Relative Wage Rigidity when? Portugal 
239 F. Andersson

K. A. Konrad

240

W. Koeniger

241 W. Koeniger

242 G. Faggio

J. Konings

243 E. Brainerd

244 S. M. Fuess, Jr. M. Millea

245 F. Andersson

K. A. Konrad

246 E. Plug W. Vijverberg

247 E. Plug W. Vijverberg

248 P. M. Picard E. Toulemonde

249 B. M. S. van Praag P. Cardoso

250 T. J. Hatton

J. G. Williamson

251 R. Yemtsov

252

R. Yemtsov

253

R. Yemtsov

254 H. Gersbach

A. Schniewind

255 H. Gersbach

A. Schniewind
Human Capital Investment and Globalization in Extortionary States

5

01/01

Labor and Financial Market Interactions: The

5

01/01

Case of Labor Income Risk and Car Insurance in the UK 1969-95

Trade, Labor Market Rigidities, and Government- 2

$01 / 01$ Financed Technological Change

Job Creation, Job Destruction and Employment 4

01/01

Growth in Transition Countries in the 90's

Economic Reform and Mortality in the Former

4

$01 / 01$

Soviet Union: A Study of the Suicide Epidemic in the 1990s

Pay and Productivity in a Corporatist Economy:

5

$01 / 01$

Evidence from Austria

Globalization and Human Capital Formation

5

$01 / 01$

Schooling, Family Background, and Adoption:

5

01/01

Does Family Income Matter?

Schooling, Family Background, and Adoption:

5

$01 / 01$

Is it Nature or is it Nurture?

The Impact of Labor Markets on Emergence and

2

$01 / 01$

Persistence of Regional Asymmetries

"Should I Pay for You or for Myself?"

3

01/01

The Optimal Level and Composition of

Retirement Benefit Systems

Demographic and Economic Pressure on

Emigration out of Africa

01/01

Labor Markets, Inequality and Poverty in Georgia

01/01

Inequality and Income Distribution in Georgia

4

01/01

Living Standards and Economic Vulnerability in Turkey between 1987 and 1994

4

01/01

Learning of General Equilibrium Effects and the

3

02/01 Unemployment Trap

Product Market Reforms and Unemployment in 3

02/01 
256 T. Boeri

H. Brücker

257 T. Boeri

258 M. Rosholm

K. Scott

L. Husted

259 A. Ferrer-i-Carbonell

B. M.S. van Praag

260 P. Cahuc

F. Postel-Vinay

261 M. Lindahl

262 M. Lindahl

263 N. Datta Gupta N. Smith

264 C. Dustmann

265 M. Rosholm

M. Svarer

266 C. Dustmann O. Kirchkamp

267 A. Newell

268 A. Newell B. Reilly

269 H. Buddelmeyer

270 B. Augurzky C. M. Schmidt

271 B. Augurzky C. M. Schmidt
Eastern Enlargement and EU-Labour Markets:

The Times They Are A-Changin':

Home versus School Learning: 
272 C. Belzil

J. Hansen

273 G. Saint-Paul

274 P. J. Pedersen

N. Smith

275 G. S. Epstein

T. Lecker

276 B. Amable

D. Gatti

277 R. Winter-Ebmer

278 T. M. Andersen

279 T. M. Andersen

280

P. Apps

R. Rees

281

G. Saint-Paul

282

J. Albrecht

A. Björklund

S. Vroman

283 M. Hagedorn

A. Kaul

V. Reinthaler

284 H. Rapoport

A. Weiss

285 J. Jerger

C. Pohnke

A. Spermann

286 M. Fertig

C. M. Schmidt
Heterogeneous Returns to Human Capital and

5

Dynamic Self-Selection

Distribution and Growth in an Economy with

5

03/01

Limited Needs

Unemployment Traps: Do Financial Dis-

3

incentives Matter?

Multi-Generation Model of Immigrant Earnings:

1

Theory and Application

The Impact of Product Market Competition on

5

Employment and Wages

Evaluating an Innovative Redundancy-Retraining 6

Project: The Austrian Steel Foundation

Welfare Policies, Labour Taxation and Inter-

2

04/01

national Integration

Product Market Integration, Wage Dispersion and Unemployment

Household Saving and Full Consumption over

7

04/01

the Life Cycle

Information Technology and the Knowledge

Elites

5

04/01

Is There a Glass Ceiling in Sweden?

5

04/01

Welfare Analysis in a Schumpeterian Growth

7

04/01

Model with Capital

The Optimal Size for a Minority

1

04/01

Gut betreut in den Arbeitsmarkt?

5

04/01

Eine mikroökonometrische Evaluation der

Mannheimer Arbeitsvermittlungsagentur

First- and Second-Generation Migrants in Germany -What Do We Know and What Do People Think 
287 P. Guggenberger

A. Kaul

M. Kolmar

288 D. A. Cobb-Clark

289 L. Cameron

D. A. Cobb-Clark

290 D. A. Cobb-Clark

M. D. Connolly

C. Worswick

291 R. T. Riphahn

292 E. Wasmer
Efficiency Properties of Labor Taxation in a

3

$04 / 01$ Spatial Model of Restricted Labor Mobility

Getting Ahead: The Determinants of and Payoffs 5

$04 / 01$ to Internal Promotion for Young U.S. Men and Women

Old-Age Support in Developing Countries:

3

$04 / 01$

Labor Supply, Intergenerational Transfers and Living Arrangements

The Job Search and Education Investments of Immigrant Families

1

04/01

Cohort Effects in the Educational Attainment of 1

05/01 Second Generation Immigrants in Germany: An Analysis of Census Data

Between-group Competition in the Labor Market 5 $05 / 01$ and the Rising Returns to Skill: US and France 1964-2000

An updated list of IZA Discussion Papers is available on the center's homepage www.iza.org. 